\title{
FUGA DA JURISDIÇÃO? REFLEXÕES SOBRE A BUSCA DE ALTERNATIVAS A JURISDIÇÃO
}

\author{
Elaine Harzheim Macedo ${ }^{1}$ \\ Eugênio Facchini Neto
}

\begin{abstract}
Resumo
O presente ensaio analisa o movimento das ADR (Alternative Dispute Resolution) - meios alternativos de resolução de conflitos -, sua origem, evolução, ideologia, especialmente nos Estados Unidos. Faz-se referência às diversas técnicas lá utilizadas, referem-se os argumentos favoráveis e, em especial, as críticas ao referido movimento. Agregam-se as experiências brasileiras seja quanto às técnicas de sumarização da jurisdição como a construção de espaços públicos ou privados para a composição alternativa de conflitos de interesses e a contribuição do novo CPC.
\end{abstract}

Palavras-chave: ADR. Resolução alternativa de conflitos. Justiça norte-americana. Direito comparado. Experiências brasileiras.

\section{INTRODUÇÃO}

Queixa-se que a justiça tradicional é demasiadamente cara e lenta para poder fazer frente ao aumento das demandas judiciais, fenômeno esse que se reproduz em todos os sistemas jurídicos do mundo ocidental. Essa a razão pela qual uma boa parte das disputas nem mesmo chegam ao sistema judiciário formal. Ou as demandas simplesmente não são ajuizadas, ou as partes procuram outras formas de dirimir seus conflitos.

O fenômeno fez com que surgisse um interesse crescente nas últimas décadas pela busca de alternativas ao modelo judicial tradicional. Embora universal, o fenômeno é mais nítido e perceptível no cenário norteamericano. Lá, mais do que em qualquer outro país, é acentuada a tendência de se implementar meios alternativos

\footnotetext{
${ }^{1}$ Doutorado em Direito pela Universidade do Vale do Rio dos Sinos (2003). Professora catedrática adjunta, permanente, da Pontifícia Universidade Católica do Rio Grande do Sul, professora palestrante da Escola Superior de Magistratura Ajuris, membro editorial da Revista da Ajuris, membro do Instituto dos Advogados do Rio Grande do Sul e da Associação Brasileira de Direito Processual Constitucional. Presidente do IGADE, Instituto Gaúcho de Direito Eleitoral. E-mail: elaine@fhm.adv.br

2 Doutor em Direito Comparado, pela Università Degli Studi di Firenze (1996-2000). Professor titular (TI) dos cursos de graduação, mestrado e doutorado em Direito da Pontifícia Universidade Católica do Rio Grande do Sul. Magistrado no Rio Grande do Sul desde 1980. Desembargador no Tribunal de Justiça do RS. E-mail: eugenio.facchini@pucrs.br
} 
de resolução de litígios, denominados genericamente de ADR - Alternative Dispute Resolution, expressão cujo sentido pode ser traduzido como "meios alternativos de resolução de conflitos".

O presente artigo tem por objetivo expor algumas experiências que vem sendo vivenciadas em diversos países, mas com especial atenção aos Estados Unidos, onde isso ocorre há mais de trinta e cinco anos, e que são pouco conhecidas entre nós. O estudo não é laudatório. Procura-se a neutralidade na exposição, buscando-se a descrição de uma situação, com a menção aos seus resultados positivos, mas também com referência às críticas que se fazem a tal sistema.

Discorre-se sobre a origem do movimento, seus objetivos, a ideologia subjacente, a experiência europeia, a norte-americana, os principais tipos de meios alternativos em uso nos Estados Unidos, os argumentos favoráveis e a crítica que se faz a essa tendência.

Ao final, dedicam-se algumas reflexões sobre a experiência brasileira nessa área, abordando os juizados especiais, arbitragem, mediação, técnicas de sumarização da jurisdição e os provimentos provisórios, bem como o novo CPC e a proposta de um processo consensual.

\section{ORIGEM DO MOVIMENTO. OBJETIVOS E IDEOLOGIA}

Em 2003, a Universidade de Florença promoveu um seminário internacional sobre meios alternativos de resolução de conflitos. Dos relatórios nacionais então apresentados, extraiu-se a conclusão de que havia uma "crescente incapacidade dos sistemas institucionais de administração da justiça civil para fazer frente à demanda de justiça proveniente dos mais diversos sujeitos, sobre matérias diversificadas e novas, incapacidade essa devida aos limites da justiça estatal, normalmente ineficiente, custosa e incerta, e talvez não apta, em alguns setores, a garantir uma satisfatória composição das lides" (VARANO, 2007, p. XI-XII).

Dentre os fatores principais que explicam a expansão do movimento em direção a formas conciliadoras de solução de controvérsias, lembrados por D. Smith (1978 apud DENTI, 1980, p. 412), destacamos dois:

1. Dificuldade de acesso à justiça ordinária pelos mais carentes, e o custo e duração do processo ordinário para aqueles que podem pagar por tal acesso.

2. Crescente insatisfação com o formalismo e tecnicismo imperante no ambiente judiciário, conjuntamente com a valorização de um papel mais ativo das próprias partes na tomada de decisões que dizem respeito à sua vida privada.

Esta espécie de "fuga da jurisdição" em direção a formas alternativas de resolução de conflitos não segue um paradigma único. Ao contrário, são diversificadas as experiências em curso.

Frequentemente estas iniciativas são descritas com expressões diversas. Cada uma delas tende a pôr em evidência um ou outro aspecto que se entende mais relevante; fala-se, assim, em ADR (Alternative Dispute 
Resolution) como técnica de "justiça informal” (para sublinhar sua simplicidade), ou então se fala em "procedimentos sumários" (para destacar sua celeridade), ou então de procedimentos que facilitam o "acesso à justiça" (para realçar sua reduzida onerosidade ou até a sua gratuidade), ou então como uma espécie de "justiça menor" (apontando para o fato de que esses meios alternativos se ocupam de questões de módico valor).

O que unifica todas essas experiências é o objetivo comum: trata-se de resolver litígios com o uso de técnicas processuais simplificadas, menos custosas e mais céleres (ALPA, 1997, p. 291-292).

Vittorio Denti (1980, p. 422) identifica duas tendências relativamente ao movimento em direção a formas alternativas de resolução de litígios: uma tendência à desformalização e outra tendente à deslegalização.

Quanto à primeira tendência - no sentido de uma desformalização -, funda-se ela na tomada de consciência no sentido de que a acentuação das garantias formais no direito processual civil contemporâneo conduziu a um aumento do custo e da duração do processo, "tornando-o um instrumento inadequado para certos tipos de lide que exigem uma rápida intervenção na composição dos conflitos". Por outro lado, também é consensual a constatação de que é "impossível resolver o problema do acesso à justiça dos jurisdicionados carentes através do aumento generalizado de assistência judiciária gratuita”, por causa do seu custo intolerável. Além disso, segundo Denti, o aumento quantitativo e a maior complexidade do trabalho do juiz moderno não podem ser enfrentados mediante o simplório aumento constante do quadro de magistrados. Há limites orçamentários não ultrapassáveis, diante da necessidade de o Estado social contemporâneo direcionar os recursos limitados para obras sociais que aliviem o presente e transformem o futuro (educação, saúde, saneamento básico, obras de infraestrutura, etc), em vez de aumentar ilimitadamente a verba direcionada a um setor do Estado que se ocupa em dirimir conflitos passados. Ou seja, exige-se que haja ganho de eficiência, fazendo-se mais e melhor com a verba orçamentária disponível. Essa é outra razão pela qual se sustenta que a diminuição do volume de trabalho dos magistrados deve passar também pela composição extrajudicial de lides de menor complexidade, reservandose o recurso à justiça tradicional, com suas inerentes garantias, às causas de maior importância e complexidade.

A outra tendência apontada por Denti - delegalizzazione das controvérsias - não é um fenômeno propriamente novo. Realmente, diz ele, "na origem da criação dos 'escritórios de paz e de conciliação' (bureaux de paix et de conciliation), logo após a Revolução francesa, encontrava-se a fé iluminista na razão natural do homem em desfavor da artificial reason dos juristas e dos juízes", bem como uma desconfiança em relação à profissão forense e ao mundo dos juristas. Deslegalização significa, nesse contexto, desde as origens históricas do fenômeno, a busca de uma solução não legalista das controvérsias, e, portanto, com maior ênfase na prevalência da composição da lide do que na definição do certo e do errado (1980, p. 426-427).

Em suma, como afirma E. Silvestri: 


\begin{abstract}
A difusão dos métodos alternativos do tipo conciliatório representa uma evidente rejeição da 'cultura da decisão' em proveito daquela que se poderia definir como uma 'cultura do compromisso'. A tendência em direção à deregulation atinge também a administração da justiça: ao processo visto como instrumento através do qual são implementados os valores incorporados nas normas do ordenamento, prefere-se uma 'gestão privada' da solução das controvérsias. Isto significa que é reconhecida às partes uma substancial liberdade para escolher seja o procedimento tido como o mais adequado para atingir um acordo, seja o conteúdo em si do acordo. Nesse contexto, a autonomia privada pode permitir às partes a definição da controvérsia de acordo com critérios mais flexíveis, não suscetíveis de serem adotados por um juiz, vinculado que está ao princípio da legalidade (SILVESTRI, 1999, p. 327-328).
\end{abstract}

Se é um menor rigorismo e formalismo que se deseja, então se poderia pensar seriamente em uma reforma processual que concedesse uma maior flexibilidade ao juiz para conduzir o processo, adotando-se efetivamente um modelo de tutela diferenciada de resolução de litígios. Além disso, poder-se-ia permitir ao juiz faculdades mais amplas de uso da equidade (o Código Civil de 2002 acolheu essa tendência ${ }^{3}$ ), além de incentiválo a aplicar a lei com maior liberdade interpretativa, não só quanto à resolução do conflito, mas igualmente em relação ao próprio procedimento, com a adoção de mecanismos adequados de materialização do processo e sumarização da jurisdição

Outro campo propício à expansão de um modo consensual de resolução de conflitos é aquele que os sociólogos chamam de "total institutions", isto é, instituições como escolas, hospitais, grandes empresas, ofícios burocráticos, condomínios, nas quais as pessoas são compelidas a conviver juntas e a manter contato diário com seus colegas, vizinhos, etc. Em tais situações, a técnica da chamada avoidance (to avoid = evitar), ou seja, o afastamento daqueles ambientes quando surge um conflito importante, é mais difícil, às vezes impossível, pois envolveria a necessidade de mudar de trabalho, profissão, escola, cidade ou bairro, etc. - alternativas essas que não se podem adotar tão facilmente. Nestes casos, torna-se evidente que uma solução em moldes tradicionais do conflito, no sentido de examinar retrospectivamente o litígio e indicar qual das partes tem razão e quem está errado, em vez de resolver o conflito, acaba por exacerbá-lo ainda mais. A solução melhor, em tais condições, é a que olhe o conflito em termos prospectivos, mirando o futuro, buscando manter as relações pessoais e serenar os espíritos por meio de uma conciliação.

Um dos meios alternativos de resolução de conflitos mais em voga no direito comparado é a mediação4. Cornu e Foyer (1996, p. 54) explicam que a mediação representa um 'apelo à participação', no sentido que o mediador não tem nem o poder, nem o dever de resolver o conflito. Sua tarefa é aquela de auxiliar as partes a

\footnotetext{
${ }^{3}$ No campo da responsabilidade civil, por exemplo, o Código Civil de 2002 expressamente autorizou o julgamento por equidade, em inúmeras situações. No novel estatuto, o julgamento equitativo comparece às vezes como exceção ao princípio da reparação integral (como nos casos de responsabilidade extracontratual previstos nos arts. 928; 944, parágrafo único; 952, parágrafo único; bem como, no plano contratual, nos arts. 413; 738, parágrafo único), e às vezes como princípio autônomo (como é o caso do art. 953, parágrafo único; art. 954; e em todos os demais casos de arbitramento dos danos não patrimoniais).

${ }^{4}$ Essa tendência também é válida para a Inglaterra, segundo Neil Andrews, "A discussão sobre os meios alternativos para resolução de conflitos tem mostrado certa tendência a considerar mediação como uma forma ligeiramente mais aconselhável”. (ANDREWS, 2012, p. 50).
} 
elaborar um projeto próprio de solução do conflito, ou, no máximo, ajudá-las a identificar os pontos de desacordo insuperáveis. Evidentemente que isso pressupõe que as partes estejam dispostas a encontrar uma solução para seu conflito em bases cooperativas.

De acordo com um dos maiores especialistas mundiais em mediação, Christopher W. Moore (1998, p. 324), numa perspectiva internacional, "sistemas que utilizam a mediação têm sido desenvolvidos para lidar com grandes números de disputas de emprego, acusações de discriminação, queixas de consumidores e controvérsias ambientais".

O sucesso da mediação depende muito da posição do mediador relativamente às partes. Quanto maior for sua autoridade, tanto maior será a probabilidade de êxito da composição amigável. Por outro lado, se é verdadeiro que o conhecimento das normas jurídicas não é tão relevante quanto no sistema tradicional de justiça, permanece o fato de que as regras jurídicas desempenham um grande papel para o esclarecimento da matéria controvertida. Da conjugação destes dois fatores resulta que o juiz é considerado quase sempre como o melhor mediador (BIERBRAUER; FALKE; KOCH, 1993, p. 54), desde que tenha uma preparação adequada para desempenhar tal papel. Ressalte-se, porém, que há certo consenso no sentido de que o mediador, por definição, não deve ser o magistrado, mas sim um terceiro. O papel mais adequado para o juiz desempenhar seria, assim, o de conciliador.

De fato, as experiências norte-americana e alemã mostram que as perspectivas de uma resolução consensual são muito mais favoráveis quando é o próprio juiz encarregado de resolver o conflito que indica às partes os possíveis desenlaces para o conflito (SCHLOSSER, 1989, p. 1021).

A seguir, veremos algumas experiências em curso no direito comparado.

\section{A EXPERIÊNCIA EUROPEIA}

Em 1999, na reunião de Tampere, o Conselho da Europa convidou os países membros a instituir procedimentos extrajudiciais para garantir um melhor acesso à justiça. Em razão disso, a Comissão da União Europeia apresentou, em 2004, uma proposta de diretiva a esse respeito, com ênfase no mecanismo da mediação. Em março de 2007 o Parlamento Europeu aprovou tal diretiva.

Ainda no âmbito internacional, os "Principles of Transnational Civil Procedure", aprovados em conjunto pela American Law Institute e pelo UNIDROIT, em 2004, que pretendem ser um modelo para as legislações nacionais, também tratam do tema. O principle 24.2 dispõe que: "The court should facilitate parties's participation in nonbinding alternative dispute-resolution procedures at any stage of the proceeding" (em tradução livre: "o juízo deverá facilitar a participação das partes em procedimentos alternativos de resolução de conflitos, de natureza facultativa, em qualquer estágio do procedimento"). 
Na União Europeia (CHIARLONI, 1995, p. 135), sente-se uma preocupação específica com a proteção do consumidor, como se vê do memorandum apresentado pela Comissão Europeia ao Conselho da Europa, em 4 de janeiro de 1985 ("A proteção jurídica dos consumidores", suplemento 2/75 do Boletim da Comissão Europeia, Luxemburgo, 1985). Parte-se da premissa que se deve garantir aos consumidores uma eficiente tutela de seus direitos fundamentais conexos a relações de consumo. Ressaltou-se, em tal documento, que o reconhecimento de tais direitos não é pleno, se não for efetivo e que a efetividade só é alcançada se for facilitado o acesso à justiça, com a disponibilização de procedimentos judiciais simplificados. As propostas do conhecido memorando foram acolhidas pelo Conselho da Europa com a Resolução de 25 de junho de 1987. Em 1993, a Comissão Europeia aprovou o chamado "Livro Verde" dispondo sobre o acesso dos consumidores à justiça, prevendo o uso harmônico e não excludente de procedimentos judiciais e extrajudiciais (ALPA, 1997, p. 299).

A partir de uma análise de direito comparado, constata-se que todos os ordenamentos contemporâneos procuraram resolver o problema da chamada 'informal justice' por vias nem sempre iguais. Nos sistemas romanogermânicos predominou a tentativa de enfrentar o problema com reformas processuais tendentes a simplificar o procedimento, encorajar soluções consensuais, ampliar tutelas cautelares e antecipatórias, aumentar os poderes do juiz para que ele possa agir no sentido de uma mais rápida solução do litígio e buscar o reequilíbrio processual de partes materialmente desiguais. Esses mecanismos endoprocessuais foram adotados com o intuito de manter sob o controle do judiciário o sistema de composição dos litígios, afastando-se do modelo norte-americano, que tendencialmente rompe com o modelo estatal de monopólio da jurisdição. Como variável, constata-se a uma revalorização do instituto da arbitragem 5 .

Inúmeros fatores atuam para frear o desenvolvimento de sistemas de informal justice na Europa. Antes de tudo, o peso de uma tradição milenar a favor da justiça togada. Em segundo lugar, o conexo mito da unidade da jurisdição, que faz ver com extrema desconfiança qualquer tentativa de erosão do monopólio atribuído aos juízes estatais. Um ulterior motivo, provavelmente o mais significativo, é o fato de que o procedimento formal regular dos sistemas judiciários europeus ocasiona menos problemas relativamente a custos e complexidade técnica, do que aquilo que acontece com o adversary system norte-americano (CHIARLONI, 1996, p. 699).

Segundo P. Schlosser (1989, p. 1006-1008), o movimento em direção a alternativas ao processo judicial é mais forte nos Estados Unidos do que na Europa porque aquele país, desde o final da segunda guerra mundial, é o principal mercado para as novas ideias, inclusive no campo jurídico. Além disso, o direito processual norteamericano, por causa da pretrial discovery, é bem mais custoso e demorado do que o congênere europeu. Em terceiro lugar, o fato de que, salvo exceções expressamente previstas em lei, não há previsão de ressarcimento de

\footnotetext{
${ }^{5} \mathrm{Na}$ Inglaterra, a lei de arbitragem é de 1996 (Arbitration Act). Segundo Andrews, as principais razões pelas quais as partes de um litígio comercial - onde ela é mais frequente - optam pela arbitragem, além da sua maior celeridade, é a confidencialidade e controle das partes (que envolve a possibilidade de escolher o árbitro, ao contrário da justiça formal em que não se escolhe o juiz, bem como a possibilidade escolha das regras de fundo e do procedimento mais adequado ao caso) (ANDREWS, 2012, p. 50).
} 
despesas processuais, ou seja, não é adotado o instituto da sucumbência em solo norte-americano. Ainda que vencendo a causa, a parte vencedora gasta ingentes somas que normalmente não lhe são reembolsadas. Em quarto e último lugar, o juiz de common law não está habituado a se envolver ativamente no processo. Em seu papel clássico, comporta-se como um árbitro neutro, somente levando em consideração o que as partes diretamente the apresentam, ainda que nas últimas décadas reformas processuais têm sido introduzidas naquele país, no sentido de tornar o juiz processualmente mais ativo, inclusive conferindo-lhe poderes conciliatórios.

Por outro lado, não se pode esquecer que, nos Estados Unidos, aproximadamente 95\% das causas são compostas diretamente pelas partes antes da sentença final (VARANO, 2007, p. IX). Assim, em realidade, o movimento em direção às $\mathrm{ADR}$ significa uma tentativa de compelir as partes a uma mais precoce tentativa de resolução do litígio, tentando evitar que o acordo seja alcançado apenas "on the courthouse steps" (nas escadarias do tribunal), somente depois que elevadas somas já tenham sido gastas na fase do pretrial ${ }^{6}$. Este elevado índice de extinção de processos por acordo alcançado pelas partes, antes da sentença, não se verifica em outros sistemas judiciários. Este contexto não pode ser desconsiderado em qualquer tentativa de imitar formas de ADR fora dos Estados Unidos.

Isso explica o recente impulso que tais formas alternativas à jurisdição estão tendo na Inglaterra, especialmente após a grande reforma processual de 1998/99, com a introdução das Civil Procedure Rules, pois também lá "uma porcentagem muito alta de ações civis inglesas não chega até o julgamento" (ANDREWS, 2012, p. 347 $)^{7}$. Neste país tem havido um sensível aumento do interesse em relação aos modos alternativos de resolução de conflitos. Inúmeras organizações envolvidas com procedimentos extrajudiciais foram criadas já há alguns anos, como o Centre for Dispute Resolution (CEDR), o British Academy of Experts, a Chartered Institute of Arbitrators, o IDR Europe Limited (especializada em mediação), o Royal Institute of Chartered Surveyors, a Society for Construction Arbitrators, o Forum for Initiatives in Reparations and Mediation (FIRM), etc (CAPPELLETTI, 1993, p. 282-294). Note-se que na reforma processual de 1998/99 foram introduzidos os chamados "pre-action protocols", com o declarado propósito de forçar as partes a tentarem acordos antes de proporem uma ação.

Na Alemanha, o aumento do volume de processos fez com que se buscassem estratégias de resolução de disputas out of court. Estima-se que mais de $70 \%$ de todo o potencial contencioso civil relativo a seguros vem sendo resolvido fora do sistema ordinário de justiça, principalmente por atuação dos advogados e das companhias de seguro. Os modelos mais utilizados seriam aqueles da tradicional arbitragem e da conciliação extrajudicial. $\mathrm{Na}$ esfera judicial, a difusão do chamado Stuttgart Model permitiu uma sensível redução do tempo de tramitação dos

${ }^{6}$ Sobre o tema, vide DE PALO; GUIDI,1999, p. 17. Para um confronto entre a situação americana e a europeia (especialmente a italiana), consultar as páginas 125 e seguintes.

${ }^{7}$ Segundo Michele Taruffo, somente " 2 a 3 por cento das causas iniciadas sobrevivem à fase preliminar e chega ao trial" (2013, p. 21). 
processos, pois já em 1997 uma causa padrão estava sendo decidida numa média de seis a nove meses junto às cortes estaduais (GOTTWALD, 1997, p. 753-757).

Uma área em que ocorreu um notável deslocamento em direção à mediação é aquela dos conflitos familiares. Sirva de exemplo a figura do médiateur francês, que integra associações especializadas em tal setor, recebe uma preparação multidisciplinar específica e está submetido a um código deontológico próprio.

Segundo Loïc Cadiet (2007, p. 70), na França os Modes Alternatifs de Règlement des Conflits - MARC, como são lá chamados, começaram a surgir na metade da década de noventa e "são menos uma categoria jurídica e mais um estado de espírito" a designar "o conjunto de procedimentos dirigidos a uma solução amigável dos conflitos", judicial (conciliação e mediação judiciária) ou extrajudicialmente (conciliação extrajudicial e mediação extrajudicial, subdividida esta em mediação espontânea, mediação institucional e mediação instituída).

Na América Latina, limitar-nos-emos a referir que a Argentina dispõe, desde outubro de 1995, de uma interessante Ley de Mediación y Conciliación Civil y Comercial (Ley 24573), cujo art. $1^{\circ}$ impõe genericamente a obrigação das partes submeterem-se à mediação prévia ('con carácter obligatorio') antes de ajuizaram uma ação.

Diante de sua maior importância, passaremos a analisar, agora, a experiência norte-americana.

\section{O CASO NORTE-AMERICANO. AS PRIMEIRAS EXPERIÊNCIAS}

A complexidade, o tecnicismo, os custos elevados, do tradicional processo judicial norte-americano, inspiraram diversas tentativas orientadas a encontrar um modo mais econômico e rápido de solução dos litígios. Muitos são os defensores de tal orientação. O último Presidente da Suprema Corte americana, por exemplo, avalia positivamente esse movimento, no qual vê um antídoto aos excessos do denominado adversary procedure (sistema processual acusatório, utilizado na common law). Partindo da premissa de que nem todas as causas necessariamente precisam ser veiculadas e discutidas no âmbito de um procedimento formal e completo, ele percebe no juiz uma espécie de manager (administrador, gerente, dirigente) processual, que teria, além de suas tradicionais atribuições, a função de encaminhar as demandas ao tipo de procedimento (alternativo) mais adaptado às suas peculiaridades (REHNQUIST, 1993, p.9).

Nos Estados Unidos costuma-se referir que o início do movimento a favor dos modelos alternativos ao processo clássico coincide com um simpósio jurídico ocorrido em 1976, para celebrar o septuagésimo aniversário

\footnotetext{
${ }^{8}$ Esse modelo baseia-se na premissa de que o papel do conciliador (no caso, o juiz), é bastante facilitado quando ele conhece os fatos da causa. Assim, na primeira fase, segue-se o procedimento escrito: à introdução da demanda segue-se a resposta e uma réplica. Depois, os autos são conclusos ao juiz, que marca uma audiência em curto prazo. Nesta audiência, o juiz propõe uma solução. As partes se afastam para falar com seus advogados e em seguida voltam para manifestar-se sobre a proposta. Se a conciliação não ocorre, parte-se para a instrução do feito. Depois de ouvir as testemunhas, o juízo novamente propõe um acordo, que, desta fez, reveste o caráter de uma "proposta do juízo", ou seja, a corte manifesta às partes qual será o possível êxito da causa. Em vista desta proposta, muitas vezes as partes resolvem conciliar (BENDER, 1993, p. 431 et seq).
} 
do conhecido discurso de Roscoe Pound, um dos maiores juristas da primeira metade do século XX, sobre o tema "The Causes of Popular Dissatisfaction with the Administration of Justice". Observou-se, naquele evento, que a despeito de todos os aperfeiçoamentos introduzidos no sistema judiciário e não obstante as inúmeras alterações e inovações no âmbito do processo civil, nos setenta anos transcorridos desde o discurso de R. Pound, persistia o baixíssimo índice de aprovação popular em relação ao funcionamento do poder judiciário e ao serviço por ele prestado. Diante de tal percepção, defendeu-se, no referido simpósio, que talvez pouco adiantasse reformar o processo civil tradicional. A coisa correta a fazer, foi então sustentado, seria "afastar do judiciário algumas espécies de controvérsias, que deveriam ser desviadas para órgãos alheios ao aparato judicial, de natureza particular, e que operassem segundo um procedimento mais flexível e informal" (SILVESTRINI, 1999, p. 323). Com isso, seria mantido o processo civil clássico da Common Law para as demandas mais complexas, de maior valor econômico e envolvendo partes capazes de enfrentar o custo de tais demandas.

As primeiras tentativas nesse sentido surgiram no final dos anos 70, de modo empírico. $\mathrm{O}$ juiz federal $\mathrm{T}$. Lambros, do Distrito Norte do Estado de Ohio, criou o summary jury trial, enquanto os seus colegas do Distrito Norte da Califórnia implantaram a early neutral evaluation (ENE), tema mais adiante abordado.

Em 1985, o Congresso decidiu financiar oito programas 'pilotos' de arbitragem endoprocessual obrigatória. Posteriormente, em 1988, o Judicial Improvements and Access to Justice Act (Lei sobre aperfeiçoamento judicial e acesso à justiça) não somente autorizou o prosseguimento das experimentações, mas inclusive as incentivou e ampliou.

Dois anos depois, o Civil Justice Reform Act (Lei sobre a reforma da justiça civil), de 1990, favoreceu a afirmação e o desenvolvimento das ADRs dentro da justiça federal (DE PALO; GUIDI, 1999, p. 19).

O conceito formal das ADR foi assim formulado pela lei federal conhecida como Alternative Dispute Resolution Act of 1998: "For purposes of this chapter, an alternative dispute resolution process includes any process or procedure, other than an adjudication by a presiding judge, in which a neutral third party participates to assist in the resolution of issues in controversy, through processes such as early neutral evaluation, mediation, minitrial, and arbitration...."

Uma área em que já há muito tempo os serviços de mediação vinham sendo utilizados é a de conflitos familiares. Informa Cappelletti (1993, p. 290 $)^{10}$ que uma National Family Conciliation Council (NFCC) foi instituída em 1982, sem fins lucrativos. Dez anos depois, a essa associação já haviam se filiado mais de cinquenta

\footnotetext{
${ }^{9}$ Em tradução livre: "Para os fins desse capítulo, um processo de resolução alternativa de litígios abrange qualquer processo ou procedimento, não presidido nem julgado por um juiz togado, em que uma terceira parte neutra participa para auxiliar na resolução de questões controvertidas, através de procedimentos como análise precoce e neutra, mediação, mini-julgamento, e arbitragem..." ${ }^{10}$ Cappelletti refere que também no Canadá foi desenvolvida uma técnica de mediação especificamente destinada aos conflitos familiares. Esta mediação ocorre tanto em bases voluntárias, como de forma obrigatória para as partes, desenvolvendo-se junto a mediadores judiciais que integram o staff do juízo, ou através de mediadores particulares (1993, p. 291).
} 
organizações. Em 1986 foi criada a Family Mediators Association (FMA), voltada especificamente à mediação de conflitos familiares.

A crescente importância do tema relativo às ADR nos Estados Unidos pode ser percebida também pelo fato de que com certa frequência casos envolvendo ADR chegam até à mais alta corte de justiça do país. Exemplificativamente, somente no ano judiciário 1994-95 (o ano judiciário americano inicia em setembro em vai até junho do ano seguinte), a Suprema Corte decidiu nada menos do que quatro casos relativos a ADR (o que, diante do escasso volume de processos julgados a cada ano, representa em torno de $4 \%$ dos casos apreciados naquele período), e em todos eles reafirmou sua posição favorável a essa técnica (GUILL, 1997, p. 1313).

Os meios alternativos de resolução de conflitos nos Estados Unidos não seguem um padrão único. Há uma grande variedade de "modelos", que se encaixam em algumas classificações elementares. É o que veremos a seguir.

\section{TIPOLOGIA BÁSICA DAS ADR}

Alguns dos procedimentos de $\mathrm{ADR}$ possuem caráter obrigatório ${ }^{11}$, enquanto outros - a maioria - são facultativos. Ressalte-se, todavia, que ainda quando obrigatória a ativação de algumas formas de ADR, o seu resultado nunca é vinculante, pois a parte interessada pode sempre requerer um novo julgamento pela justiça ordinária. Trata-se substancialmente de uma simples "condição de procedibilidade da ação civil" (DE PALO; GUIDI, 1999, p. 7).

Além da classificação das ADR em obrigatórias/facultativas, uma diversa classificação permite distinguir os modelos conciliatórios (consensual-oriented model) dos modelos decisionais (decision-oriented model).

O primeiro deles - modelo conciliatório - visa a compor a controvérsia através de uma solução acordada entre as partes. Várias técnicas inserem-se nesse modelo, como é o caso da mediation, da early neutral evaluation e do summary jury trial.

Já o modelo decisional (decision-oriented) procura a solução dos conflitos através de uma decisão emanada de um terceiro, que não o juiz estatal. $O$ arquétipo desse último modelo é a arbitragem.

O modelo dito conciliatório foi o que obteve muito maior sucesso na nação norte-americana.

A summa divisio que se pode traçar a respeito da ADR, porém, distingue, de um lado, uma "justiça alternativa privada”, reconhecendo-se a autonomia das partes em litígio para dirigirem-se a qualquer uma das numerosas organizações privadas que fornecem esse tipo de serviço nos Estados Unidos e, por outro lado, uma “court-annexed ADR" (também denominada de court-ordered, court-sponsored, ou ainda court-managed ADR). Trata-se de uma "justiça alternativa pública” (DE PALO; GUIDI, 1999, p. 7).

\footnotetext{
${ }^{11}$ Ressaltando que a lei federal de 1998, antes citada, excluiu a hipótese de arbitragem endoprocessual obrigatória na justiça federal, em virtude das observações contidas no relatório Rand de 1996 (que será referido mais adiante) e no parecer da Judicial Conference sobre a sua escassa eficácia.
} 
À guisa de demonstração do interesse sobre o tema, refira-se que todas as Faculdades de Direito norteamericanas vêm introduzindo em seus currículos regulares disciplinas e cursos relativos à negociação de causas e outras técnicas necessárias ou convenientes para uma resolução alternativa das controvérsias (RE, 1986, p. 316), principalmente as de natureza consensual. E isso ocorre porque a expansão da utilização dos procedimentos de ADR mudará também o paradigma profissional do advogado americano, que passará de 'adversarial advocate' a 'legal counselor' (de "advogado litigioso" a "conselheiro jurídico") (GUILL, 1997, p. 1313). Isso significa que, nesse novo paradigma, exige-se um advogado que não esteja preparado somente para o modelo "the winner takes all" ("o vencedor leva tudo"), mas que esteja também capacitado para analisar globalmente a situação de ambos os potenciais contendores (e não somente os interesses do seu cliente) de modo a poder identificar uma solução que seja razoável para ambos, evitando o conflito ou superando-o com menor custo, tempo e desgaste.

Algumas das $\mathrm{ADR}$ são vinculadas à própria justiça estatal. Outras são dela independentes. É o que veremos a seguir.

\section{DIMENSÃO SUBJETIVA DAS ADR - QUEM SÃO OS ATORES?}

É praticamente impossível fazer um inventário de todas as formas de ADR em uso nos Estados Unidos, uma vez que, além daquelas que de alguma maneira estão vinculadas ao poder judiciário, existem inúmeras outras que são desprovidas de qualquer ligação. Segundo um recente levantamento, contam-se mais de mil ADR brokers (corretores de ADR), os quais buscam oferecer um 'produto' diferenciado, levando em conta o tipo de controvérsia que as partes pretendem definir.

Além dos serviços de arbitragem, conciliação e mediações oferecidas pela American Arbitration Association (a mais antiga e potente associação operante no setor dos métodos alternativos) e pelo seu mais agressivo concorrente, o JAMS (Judicial Arbitration and Mediation Services - empresa privada que detém o monopólio das ADR em alguns Estados), existe uma miríade de associações, organizações, entidades e profissionais que oferecem seus serviços nessa verdadeira 'indústria' dos métodos alternativos (SILVESTRI, 1999, p. 325), dentre as quais merece referência a empresa "Judicate, Inc.", que criou e administra o "Sistema Nacional de Cortes ${ }^{12}$ Privadas" (The National Private Court System). Trata-se de uma organização integralmente privada, que se dispõe a decidir as controvérsias, com base na legislação estatal e não simplesmente por equidade, desde que as partes interessadas estejam de acordo e se comprometam a aceitar a decisão final. Trata-se de verdadeiras

\footnotetext{
${ }^{12}$ Esclareça-se que o vocábulo "Court", nos sistemas que integram a Common Law, tem o amplo significado de unidade jurisdicional, seja de que instância for. Conforme o contexto, seu significado, no caso concreto, poderia ser traduzido, em linguagem adaptada ao nosso sistema, por juízo, juizado, vara, tribunal, turma ou câmara julgadora, etc.
} vol.09, n. 01, Rio de Janeiro, 2016.pp. 510-544 
unidades de arbitragem, normalmente presididas por juízes aposentados ${ }^{13}$, que usam togas, ouvem testemunhas sob juramento e atuam sob o princípio do contraditório - ou seja, vestem-se como juízes, agem como juízes, decidem como juízes, mas não são (ou não são mais) juízes. Esses “juízes particulares” são relativamente bem remunerados - de US\$150 a US\$300 a hora de trabalho (ABRAHAM, 1998, p. 156) ${ }^{14}$.

Todavia, afora essa experiência, que posteriormente foi expandida, a maior parte dos modelos alternativos de justiça atualmente em uso nos Estados Unidos possui ligação com o aparato Judiciário. É o modelo chamado "endoprocessual".

\section{TÉCNICAS DE ADR ENDOPROCESSUAIS E EXTRAPROCESSUAIS}

J. Resnik (1997, p. 699) indica as seguintes mais conhecidas técnicas alternativas de resolução de conflitos nos Estados Unidos, que serão analisadas mais abaixo: a court-annexed arbitration, a mediation, o summary jury trial, o minitrial, a early neutral evaluation, e as judicial settlement conferences.

A esses procedimentos O. Chase (1988, p. 942-943) acrescenta ainda a "final-offer arbitration" (no qual o árbitro deve escolher entre uma das hipóteses de composição do litígio proposta por cada uma das partes. Isso estimula ambas as partes a propor soluções razoáveis, pois se uma delas apresentar uma proposta exorbitante ou desarrazoada, o árbitro poderá escolher a proposta ofertada pela parte contrária), e a "one-way arbitration" (onde somente uma das partes fica vinculada ao laudo arbitral).

Passaremos, agora, a referir alguns dos mais conhecidos meios alternativos de resolução de conflitos em uso nos Estados Unidos.

\section{A court-annexed arbitration}

A court-annexed arbitration ${ }^{15}$ (arbitragem vinculada ao juízo) na fase inicial do processo, as partes devem se submeter a um árbitro ou a um colégio arbitral composto geralmente por advogados ou juízes aposentados. A solução indicada por esses árbitros não é vinculante para as partes, que podem se dirigir ao juízo onde tramitava a demanda, pedindo a instauração do chamado "trial de novo" (nova análise integral da causa), no prazo de trinta

\footnotetext{
${ }^{13}$ Interessante notar que, em agosto de 2014, a Escola Nacional da Magistratura (ENM), da Associação dos Magistrados Brasileiros (AMB), entidade que congrega a quase totalidade dos magistrados brasileiros promoveu o primeiro curso de "Mediação e Conciliação para Magistrados Aposentados", visando a capacitá-los para essas novas funções. Ou seja, trata-se de mais um exemplo de circulação de modelos.

${ }^{14}$ Para os padrões brasileiros, seria uma boa remuneração. Todavia, para os padrões norte-americanos, seria apenas uma razoável remuneração, quando se lembra que os melhores advogados norte-americanos já ultrapassaram a barreira dos mil dólares a hora de trabalho.

15 As causas direcionadas para resolução mediante essa técnica usualmente são relativamente simples. Muitas causas de responsabilidade civil são resolvidas mediante tal procedimento - cf. E. Silvestri, La 'court-annexed arbitration': un nuovo rimedio per un vecchio problema. (BESSONE, 1997, p. 334).
} 
dias após o conhecimento do laudo arbitral. Esta, na verdade, é justamente a característica específica da courtannexed arbitration em face da arbitragem tradicional: o laudo arbitral não é vinculante para as partes, que podem sempre pedir que desconsidere o laudo e instrua e julgue o processo. Não se trata, todavia, de um verdadeiro recurso ao juiz para que este examine eventuais erros que possam ter sido cometidos pelo árbitro, quer no exame dos fatos, quer na solução jurídica arbitrada. Isso porque o juiz inclusive nem sequer será informado daquilo que aconteceu durante a arbitragem. Somente quando o trial de novo não tenha sido pedido é que o laudo arbitral adquire valor e efeito de uma verdadeira decisão judicial.

Uma variante dessa técnica consiste na chamada "Michigan Mediation". Trata-se de uma técnica que prevê a penalização da parte que tenha recusado a proposta de solução apresentada pelo mediador, quando essa proposta posteriormente se revelar, na análise do julgador, razoável. Essa razoabilidade é aferida em termos objetivos: entende-se razoável a proposta feita pelo mediador quando a sentença acabe por reconhecer à parte que a recusou, uma vantagem não superior a $10 \%$ do valor indicado na proposta de acordo. Nesse caso, a parte que recusou a proposta do árbitro deve arcar com as despesas processuais, ainda que vencedora da demanda.

A arbitragem endoprocessual, contudo, é utilizada cada vez menos, apresentando uma tendência inversa em relação à conciliação/mediação, cada vez mais utilizada.

\section{A court-annexed mediation}

A mediação endoprocessual ( bastante padronizados. O mediador, após um esclarecimento inicial ("opening statement") em que explica o procedimento a ser adotado e seu próprio papel, ouve as partes em conjunto e, se for o caso, separadamente, buscando compreender o litígio e os pontos de discórdia. Obtendo um acordo, o mediador o reduz por escrito, ou então, dependendo da complexidade do litígio, suspende-se o procedimento para que os advogados das partes redijam os termos do acordo que, num segundo momento, serão submetidos ao mediador.

O encaminhamento do litígio para que seja submetido à mediação endoprocessual pode decorrer de iniciativa do próprio juiz da causa, ou a pedido das partes. Em muitos casos, a função de mediador é desempenhada por um magistrate judge ${ }^{16}$, embora alguns juízes federais prefiram designar advogados, juízes aposentados ou outras pessoas selecionadas especificamente para desempenhar essa função. A mediação

\footnotetext{
${ }^{16}$ Os federal magistrates judges foram criados em 1968. Originariamente eram competentes para atuar apenas na fase do pre-trial (instrução probatória, em que a atuação principal é dos advogados) e, na esfera criminal, para julgar as contravenções. Em seguida, paulatinamente a sua competência foi sendo aumentada. A lei ora em vigor - Federal Magistrates Act of 1979 -, autoriza os magistrates a presidir toda a instrução das causas civis, seja naquelas de competência do juízo monocrático, seja naquelas que contam com a presença do júri. Só poderão, porém, proferir sentenças finais nessas causas se todas as partes interessadas nisso consintam. Na esfera criminal, podem julgar as contravenções, sempre com o prévio consentimento dos imputados. Os magistrates são nomeados pelos próprios District Judges (juízes federais). Podem permanecer no cargo por um período de até oito anos, se exercerem suas funções em tempo integral (full time), ou por quatro anos, se trabalharem "part-time".
} 
endoprocessual é de longe o procedimento alternativo de resolução de controvérsias mais difundido nas cortes federais americanas ${ }^{17}$.

\section{O summary jury trial}

A outra técnica, dita summary jury trial (literalmente, "julgamento sumário por júri”, denominado por G. de Palo e G. Guidi de "juízo consultivo"), desenvolve-se perante um juiz e um júri simulado, integrado por pessoas indicadas pelo juiz. Não são produzidas provas perante o conselho de sentença (júri). $\mathrm{O}$ júri chega a um parecer opinativo (advisory judgement) baseando-se nas argumentações dos advogados, como se os fatos tivessem sido provados. Também aqui o objetivo é o de conduzir as partes a um acordo, depois de elas considerarem os possíveis resultados do processo (judicial reality check). Num estudo comparativo entre os juizados distritais que usavam esse tipo de $\mathrm{ADR}$ e aqueles que não o faziam, K. Dayton não encontrou, contudo, diferenças estatísticas significativas em relação a uma maior eficiência entre um e outro (DAYTON, 1991, p. 915-929).

\section{O minitrial}

Existe, também, o minitrial, que igualmente é um processo simulado, com a particularidade de que o júri é composto por um árbitro e por altos dirigentes das partes envolvidas. O propósito é permitir que esses executivos obtenham informações mais reais acerca da viabilidade de suas pretensões, quando colocadas em confronto real com as pretensões da outra parte. O procedimento busca estimular o exercício de mea culpa, desarmando os espíritos e abrindo a disponibilidade para um posterior acordo, onde cada uma das partes estará mais disposta a ceder um pouco, relativamente às posições iniciais. Tanto essa quanto a técnica anterior, todavia, não são muito utilizadas (DE PALO; GUIDI, 1999, p. 74 et seq).

Segundo a definição do clássico Black’s Law Dictionary (GARNER, 2004, p. 1017), minitrial é um:

Private, voluntary and informal form of dispute resolution in which each party's attorney presents an abbreviated version of its case to a neutral third party and to the opponent's representatives, who have settlement authority. The third party may render an advisory opinion on the anticipated outcome of litigation ${ }^{18}$.

\footnotetext{
${ }^{17}$ Sobre tal aspecto, vide DE PALO; GUIDI, 1999, p. 45-78.

${ }^{18}$ Em tradução livre: "uma maneira informal, voluntária e privada de resolução de conflitos em que o advogado de cada parte apresenta uma versão sumária do seu caso a um terceiro neutro, bem como aos representantes do adversário, que dispõem de poderes para transigir. Espera-se que esse terceiro neutro profira um parecer sobre o provável resultado de um julgamento sobre o caso".
} 


\section{O early neutral evaluation - ENE}

Quando o processo ainda se encontra em sua fase inicial (pre-trial ${ }^{19}$ ), o procedimento de ADR mais recomendável seria o early neutral evaluation (ENE), ou "avaliação preliminar". Nesse modelo, imediatamente após o oferecimento da contestação, os litigantes apresentam sua versão do caso, de forma sumária, a um neutral evaluator (avaliador neutro), que é um terceiro, portanto neutro, e especializado na matéria controvertida (podendo ser um advogado ou um magistrate judge). Esse terceiro elabora um parecer sobre o provável resultado da causa, onde levará em conta os aspectos fáticos envolvidos, a probabilidade ou não de que sejam provados, a dificuldade de eventuais provas, o enquadramento jurídico mais provável, bem como as tendências jurisprudenciais a respeito do tema. Esse parecer não é vinculante para as partes.

O objetivo desse procedimento é o de propiciar às partes o acesso a uma opinião isenta e com conhecimento de causa, sobre a provável solução judicial do litígio. Caso ainda assim persista o conflito e as partes insistam no prosseguimento do feito, nada do que foi discutido perante o evaluator (e menos ainda o seu parecer) é comunicado ao juiz. Apesar de se tratar de um procedimento que o Judiciário oferece às partes, sem custo para estas, atualmente não é ele muito utilizado, preferindo-se a técnica da mediation ${ }^{20}$.

\section{A settlement conference}

$\mathrm{Na}$ settlement conference (audiência de conciliação), o juiz participa das tratativas entre as partes ou entre os seus advogados, na tentativa de fazer com que elas cheguem a um acordo. Na maioria dos juizados federais distritais, essas audiências de conciliação são presididas não pelo district judge, mas por um magistrate judge (DE PALO; GUIDI, 1999, p. 79).

Inicialmente, a designação dessas audiências de conciliação ficava ao critério de cada juiz. Em 1983, porém, a obrigatoriedade da realização de tal audiência na justiça federal foi institucionalizada através da alteração ${ }^{21}$ da Rule 16 das Federal Rules of Civil Procedure ${ }^{22}$ (art. 16 do "código de processo civil federal"). A partir dessa reforma, portanto, os juízes federais devem necessariamente aprazar audiências de conciliação, onde

\footnotetext{
${ }^{19}$ Fase de instrução do processo, que antecede à audiência em juízo. Nessa fase, a atividade judicial é quase inexistente, pois cabe aos advogados providenciar na obtenção das provas. A interferência do juiz deve ser solicitada apenas quando os próprios advogados não conseguem superar os impasses surgidos. Normalmente, quem mais atua nessa fase são os magistrates judges, e não propriamente os juízes togados.

${ }^{20}$ Sobre esse procedimento, vide DE PALO; GUIDI, 1999, p. 68 et seq., e SILVESTRI, 1999, p. 329 et seq.

${ }^{21}$ Supreme Court of the United States, Order Promulgating Amendments to the Federal Rules of Civil Procedure, 97 F.R.D., P. 165, 201-213 (28 de abril de 1983).

${ }^{22}$ Equivalente, grosso modo, a um código de processo civil federal, que regula a tramitação dos processos junto à justiça federal. Cada Estado-membro possui suas próprias regras processuais (tal como ocorria no Brasil, antes de 1939), muito embora se saiba que as regras processuais vigentes nos Estados-membros se espelham substancialmente nas regras federais.
} vol.09, no. 01, Rio de Janeiro, 2016.pp. 510-544 
se busca a conciliação ou, frustrada esta, o encaminhamento do processo a um dos procedimentos alternativos de resolução de controvérsias.

\section{A appellate mediation}

Merece também referência outra experiência, denominada appellate mediation ${ }^{23}$ ("mediação recursal"), que nos últimos anos vem sendo adotada pelas federal courts of appeals. Em cada tribunal federal de recursos foram contratados de um a três settlement officers (oficiais de conciliação) para agir como mediadores. Todas as apelações que chegam ao tribunal são imediatamente submetidas a uma triagem. Se pela natureza e peculiaridades da controvérsia é percebida uma possibilidade de acordo, o mediador reúne-se (pessoalmente ou por telefone) com os advogados das partes (ou eventualmente com essas também) e procura direcioná-los a um possível acordo.

Para ser mais preciso, a intervenção do mediador (settlement officer) ocorre ainda antes da apelação propriamente dita, porque, segundo o sistema processual americano, a apelação inicia com uma "notice to appeal", ou seja, uma manifestação formal da intenção de recorrer. As Federal Rules of Appellate Procedure (Normas Federais sobre Procedimento Recursal) exigem que a notice to appeal contenha somente a especificação da parte apelante, a sentença ou parte dela da qual se recorre, bem como a identificação do tribunal ad quem. A partir de então se inicia a fase da formação dos autos do recurso (record on appeal), com a extração das peças necessárias para sua instrução. Formados os autos do recurso, inicia-se o prazo (de trinta a sessenta dias) para a apresentação dos memoriais escritos (brief), contendo a fundamentação do recurso ${ }^{24}$. Como a intervenção do mediador ocorre assim que chega a notice to appeal, mas ainda antes da formação dos autos e da apresentação dos memoriais, percebe-se a precoce intervenção daquele personagem.

Os dados estatísticos disponíveis revelam que o mediador consegue obter acordos em um número de processos equivalente àquele que um "desembargador federal" consegue julgar no mesmo período de tempo (POSNER, 1996, p. 239-240).

\footnotetext{
${ }^{23}$ Essa técnica é autorizada pelo artigo 33 das Federal Rules of Appeals: "The court may direct the attorneys, and in appropriate cases the parties, to participate in one or more conferences to address any matter that may help in the disposition of the proceedings, including the simplification of the issues and the possibility of setlement. A conference can be conducted in person or by telephone and be presided over by a judge or other person designated by the court for that purpose. (...)." (tradução livre: "O tribunal pode convocar os advogados, e em determinados casos as próprias partes, para participarem de uma ou mais audiências a fim de discutirem qualquer matéria que possa facilitar o encaminhamento procedimental do feito, buscando sua simplificação e a possibilidade de acordo. A participação em tais audiências poderá ser feita pessoalmente ou por telefone, podendo ser elas presididas por um juiz ou por outra pessoa designada especialmente pelo tribunal para tal mister."

${ }^{24}$ Sobre a tramitação dos recursos, confira-se JAMES JR.; HAZARD JR.; LEUBSDORF,1992, p. 662 e 665.
} vol.09, nº. 01, Rio de Janeiro, 2016.pp. 510-544 


\section{ALTERAÇÕES LEGISLATIVAS MAIS RECENTES}

Nos últimos anos, as regras que disciplinam o uso das Alternative Dispute Resolution foram novamente revistas. Em 1993, por exemplo, a Rule 16 das Federal Rules of Civil Procedure sofreu nova alteração, buscando fixar, com maior precisão, o papel do juiz na condução do procedimento na fase do pre-trial, no controle da discovery $^{25}$, e no auxílio que deve prestar às partes para se alcançar a resolução consensual dos litígios. Essas alterações, em seu conjunto, foram no sentido de se atribuir um papel muito mais ativo ao juiz. Isso porque o modelo clássico de juiz da common law era aquele de um juiz substancialmente passivo na condução do processo.

Além disso, as alterações levadas a efeito na reforma processual de 1993 redefiniram o conceito de ADR, que uma década antes fora qualificada como conjunto de 'procedimentos extrajudiciais'. A reforma de 1993 definiu as técnicas de $\mathrm{ADR}$ como 'procedimentos especiais para a assistência na resolução das controvérsias, nos casos autorizados pela lei ou pelas normas locais'.

Em 30 de outubro de 1998 entrou em vigor a Alternative Dispute Resolution Act of 1998, que pôs fim à fase de experimentação em matéria de ADR. Cada um dos juizados federais foi instado a integrar dentro do sistema processual, de modo estável e permanente, os procedimentos de resolução alternativa dos litígios. Essa lei federal destacou a importância da conciliação dentre os demais modelos de ADR. No caso da arbitragem, eliminou a possibilidade de imposição de pena à parte que viesse a requerer o trial de novo, ainda que não obtivesse uma sentença mais vantajosa do que o resultado indicado no laudo arbitral endoprocessual" (DE PALO; GUIDI, 1999, p. 122 et seq).

Passada, assim, a fase de experimentações, ficou definitivamente afirmada a ADR no âmbito da justiça federal, estando atualmente institucionalizada e disciplinada legalmente ${ }^{26}$.

\section{ARGUMENTOS FAVORÁVEIS AO MOVIMENTO DAS ADR}

Embora o locus natural para solução de conflitos sociais em um sistema como o nosso seja o processo judicial, não se pode deixar de reconhecer que esse instrumento não mais tem a aptidão de outrora para atingir os

\footnotetext{
${ }^{25}$ Tecnicamente, discovery significa a "disclosure by a party to an action, at the other party's instance, of facts or documents relevant to the lawsuit" (vocábulo "discovery" in: GARNER, 1995, p. 281.). Em vernáculo: "revelação feita por uma parte no processo, a pedido da outra, sobre fatos ou documentos relevantes para o litígio judicial”. No glossário fornecido por Neil Andrews, no início de sua obra, refere-se ao Discovery ou Disclosure, como uma "atividade consistente em as partes exibirem, uma à outra, as provas e as informações de que dispõem e que usariam em um futuro eventual trial in: ANDREWS, 2012, p. 21. Trata-se de uma peculiaridade do sistema processual norte-americano, em que uma das partes pode exigir que a outra lhe apresente (diretamente, sem a mediação do juiz) todos os fatos e documentos de que dispõe sobre o caso, antes da audiência de instrução, pois a parte tem o direito de não ser surpreendida por provas ou documentos novos, por ocasião do day in court.

${ }^{26}$ Sobre toda essa evolução, muito útil revela-se a consulta de J. Resnik, "Risoluzione alternativa delle controversie e processo: uno sguardo alla situazione nordamericana”. (CHASE, 1997, p. 704-706).
} 
resultados a que sua criação visou a alcançar: a composição justa e tempestiva dos conflitos (LIMA FILHO, 2003, p. 246). Daí a busca de alternativas à jurisdição.

São de duas espécies os argumentos esgrimidos a favor do movimento das ADR, uma de natureza quantitativa, outra de natureza qualitativa.

O argumento de natureza quantitativa é o mais invocado. Segundo ele, a ADR deveria ser incentivada porque é uma maneira mais eficiente de solução das disputas, de menor custo e muito mais rápida. Invocando-se a experiência inglesa, desde 1999 (quando entraram em vigor as reformas introduzidas pelo novo 'código de processo civil' (Civil Procedure Rules - CPR, que estimula o uso dos meios alternativos de resolução de conflitos bem como o uso de procedimentos sumários para causas de menor valor) e até 2010, a maior utilização das ADR acarretou a diminuição de $21 \%$ do volume de causas judicializadas (ANDREWS, 2012, p. 348).

O segundo argumento, 'qualitativo', parte de uma abordagem segundo a qual a ADR possibilita uma maior participação das partes no desenvolvimento do processo e permite a elas um maior controle sobre o resultado do processo - afinal, são elas que definem esse resultado -, bem como permite manter em sigilo certos fatos que, eventualmente, um processo regular tenderia a publicizar. Além disso, sustenta-se que a ADR oferece uma maior possibilidade de reconciliação entre as partes, garantindo uma melhor comunicação entre elas, aumentando assim a probabilidade de manutenção ou recuperação das relações interpessoais (MENKELMEADOW, 1997, p. 1871-1872). Segundo esta visão, enquanto o processo judicial ordinário "olha para o passado" da relação litigiosa, a ADR "olha para o futuro", ficando mais próxima da ideia de justiça coexistencial de que falava Cappelletti.

Uma outra e importante vantagem é a possibilidade de se alcançar soluções dificilmente alcançáveis pela via de um processo regular. Uma ilustração dessa possibilidade é dada por Neil Andrews, envolvendo uma ação de reparação de danos movida pelos genitores de uma criança falecida, cujos órgãos internos haviam sido retirados para fins de transplante, sem conhecimento e autorização dos pais. A ação fora movida contra o hospital. Após uma longa tramitação, o juiz que presidia o processo recomendou que as partes fossem submetidas a uma mediação, que resultou exitosa. As partes chegaram a um acordo que estabelecia uma indenização modesta, mas que também previa que o hospital construiria um memorial para o filho dos autores e outras crianças com as quais também havia ocorrido o mesmo, além de um formal pedido de desculpas por parte dos médicos envolvidos, e outras obrigações acessórias. Alcançou-se, assim, uma solução mais satisfatória para os pais, do que a simples transferência de um valor econômico que nem sempre representa o que as partes efetivamente buscam (ANDREWS, 2012, p. 352-353). 


\section{CRÍTICAS AO MOVIMENTO DAS ADR}

Todavia, mesmo nos Estados Unidos, onde o fenômeno surgiu há cerca de 40 anos, aparentemente já foi superada a fase de máxima expansão e a abordagem, atualmente, é mais crítica do que laudatória ${ }^{27}$.

Alguns são mais cautelosos e moderados nas críticas, como é o caso de Mauro Cappelletti, abordando o tema em escala universal. O processualista italiano, como é sabido, foi um pioneiro ao sustentar a idéia de uma justiça coesistenziale, fundada mais sobre a conciliação dos espíritos e sobre a preservação das relações, do que sobre a perspectiva do rigth-or-wrong ou do tudo ou nada. O mesmo saudoso professor enquadra o movimento da ADR na terceira onda do seu conhecido projeto de acesso à justiça, revelando também a tendência de certa privatização da justiça e um maior recurso à equidade. Porém, também ele alerta para o risco de uma justiça de segunda classe, por causa da falta de garantia de independência do juiz que opera naqueles sistemas, pelo seu menor preparo técnico e pela redução das garantias processuais. Tudo isso, porém, deve servir de alerta, segundo ele, e não de desencorajamento (CAPPELLETTI, 1993, p. 282-295).

Também Andrews, embora entendendo que os meios alternativos devem ser incentivados e produzem bons resultados, numa apreciação global, refere que há situações em que as ADR não são convenientes. É o caso, por exemplo, de quando uma das partes realmente tem um claro direito a respeito de algo - nesse caso, tal direito não deve ser 'neutralizado' por meio de um acordo em que ele abra mão de tal direito. Além disso, a opção pelo processo formal deve ser usada no caso de 'ilícitos graves'(ANDREWS, 2012, p. 355).

Já outros são mais céticos e contundentes em suas críticas. Estes costumam ressaltar dois outros motivos que contribuiriam para explicar o entusiasmo dos defensores da $\mathrm{ADR}$, ainda que não abertamente sustentados por esses.

Primeiramente, haveria o interesse de liberar os órgãos regulares de justiça dos chamados garbage cases (casos-lixo), ou seja, daqueles casos de modesto valor econômico, escassa relevância jurídica, tendentes a serem repetitivos e pouco úteis para o progresso da ciência jurídica. Com isso, a justiça ordinária ficaria liberada para tratar dos casos mais importantes, de interesse para a elite política e econômica (establishment).

Em segundo lugar, haveria o desejo de frear o ativismo judicial que vinha se manifestando em certas áreas muito importantes para o establishment, como exemplificativamente aquela concernente à tutela do consumidor (SILVESTRI, 1999, p. 324). Como uma decisão proferida por um juiz togado tem muito maior potencial de alteração da realidade social, quer chamando a atenção da imprensa, quer através da técnica dos precedentes vinculantes, se emanada por um tribunal superior, quando se percebe que os juízes perfilham uma orientação

\footnotetext{
${ }^{27}$ Esta é a opinião de E. Silvestri (1999, p. 321 et seq.), ressalvando, porém, que "tudo leva a prever que, nos próximos anos, a multibilionária indústria dos métodos alternativos continuará a proliferar, pelo menos até que os consumidores se conscientizem que o produto oferecido a um preço de "hard discount" não é necessariamente o que de melhor se pode obter no mercado".
} vol.09, nº. 01, Rio de Janeiro, 2016.pp. 510-544 
desfavorável aos setores mais interessados na manutenção do status quo, a esses passa a interessar desviar tais demandas da apreciação da justiça ordinária.

$\mathrm{Na}$ Europa, como já assinalado, a adesão às formas de ADR é menos entusiástica do que nos Estados Unidos, em razão da consciência das peculiaridades do ambiente originário, o que significa no mínimo ser inoportuno um simples 'transplante' de alguns mecanismos alternativos de solução das controvérsias.

Realmente, a premissa básica de muitos defensores das ADR consiste em ver o acordo obtido pelas partes como uma antecipação do resultado final que seria obtido através de um processo judicial, com notável economia de tempo e dinheiro. Ou seja, parte-se da ideia que o único objetivo da jurisdição seja o de compor a lide. Porém, sabe-se que este não é o único objetivo visado pela administração da justiça (SILVESTRI, 1999, p. 328). Segundo C. Dinamarco (1987, p. 206 et seq), a jurisdição possui objetivos sociais (a pacificação das partes em conflito, mediante a aplicação de critérios de justiça) escopos políticos (a participação da parte interessada, atuando processualmente, na resolução da controvérsia; afirmação da autoridade do Estado; educação do cidadão relativamente aos seus direitos), além daquele jurídico de atuação da "vontade concreta do direito".

Além disso, lembra E. Silvestri (1999, p. 328) que a difusão dos procedimentos de informal justice fez com que ressurgissem algumas preocupações que o modelo judicial clássico já havia enfrentado e resolvido. Pergunta-se, por exemplo, se a ausência de formalidades, característica de muitos procedimentos alternativos, não possa significar também ausência de garantias para a mais débil das partes em litígio. Isto porque o processo clássico e garantista pode propiciar à parte mais fraca certa proteção, ao atribuir ao juiz uma série de poderes cujo exercício teria por fim assegurar uma efetiva paridade de armas entre as partes.

O prof. Owen Fiss em seu conhecido ensaio intitulado emblematicamente "Against Settlement" (1984, p. 121-145) (Contra o Acordo), afirma que o encorajamento da conciliação é particularmente prejudicial no caso das controvérsias envolvendo public law, e que os tribunais deveriam preocupar-se em articular e implementar princípios de justiça, e não de impelir as partes a aceitar qualquer acordo apenas para pôr fim ao litígio.

Outros argumentos contrários ao uso intenso das ADR são referidos nos já citados ensaios de J. Resnik (1997, p. 713 et seq) e Oscar G. Chase (1988, p. 940), onde se referem também outros autores que são reticentes a respeito de tal movimento, por considerá-lo "politicamente conservador", já que "se propõe reservar as cortes regulares para as controvérsias empresariais impedindo o acesso ao juiz ordinário às classes sociais mais débeis".

Também sob o perfil da eficiência existem objeções às Alternative Dispute Resolution (ADR). Em 1992, a Judicial Conference ${ }^{28}$ encomendou à RAND Corporation um estudo para avaliar os efeitos das iniciativas adotadas pelos vários órgãos da justiça federal no campo da ADR. Após quatro anos de análises e pesquisas de

\footnotetext{
${ }^{28}$ Criada em 1922, a Judicial Conference of the United States é o órgão máximo da administração judiciária federal norteamericana. É presidido pelo Presidente da Suprema Corte e é composto por todos os presidentes (Chief Judges) das Federal Court of aos juízes.
} 
campo, a RAND Corporation apresentou, em 1996, o resultado de seus estudos, que a muitos pareceu desencorajante. De fato, ainda que não sinalizasse efeitos negativos, o estudo exclui a existência de motivos que justificassem recomendações em favor da adoção de programas de ADR no âmbito da justiça federal, porque os projetos-pilotos experimentados até então não teriam tido um grande impacto na economia de tempo e dinheiro ${ }^{29}$.

Apesar disso, contudo, a Judicial Conference, baseando-se nos dados fornecidos por um estudo independente do Federal Judicial Center $^{30}$, reconheceu os efeitos positivos de alguns aspectos do programa experimental das ADR e acabou por adotar uma via intermediária: nem estender a obrigatoriedade da adoção de programas de ADR para todas as 94 cortes federais de primeira instância, nem tampouco eliminar a ADR endoprocessual. Baseado nessa orientação é que foi encaminhada e aprovada a lei sobre resolução alternativa das controvérsias (ADR) de 1998.

O Circuit Judge H. T. Edwards pensa ter encontrado um ponto de equilíbrio ideal entre o espaço próprio da justiça ordinária e aquele adequado às diversas $\mathrm{ADR}$ :

Some would respond that judges are generalists and yet we trust our state and federal judiciary to resolve a broad range of disputes. This argument, however, is deceptive because judges are specialists in resolving issues of law. Law aims to resolve disputes on the basis of rules, whereas alternative dispute resolution mechanisms turn to nonlegal values. If disputes are to be resolved by rules of law, the legal experts designated by our state and federal constitutions - that is, the judges - should resolve them. If nonlegal values are to resolve disputes, we should recognize the need for substantive expertise (EDWARDS, 1986, p. 683$684)^{31}$.

Além disso, olvida-se que nem sempre é suficiente a obtenção de um acordo para que a harmonia e concórdia entre as partes sejam definitivamente restabelecidas. Isso porque frequentemente surgem problemas e discordâncias na fase de execução do acordo. No caso norte-americano, por exemplo, costuma-se referir que muitas das atividades do lá chamado managerial judge (juiz-gerente ou juiz-dirigente - no sentido de juiz que se envolve efetiva e ativamente na condução do processo) são desempenhadas exatamente na fase do post-trial (fase

\footnotetext{
${ }^{29}$ A Judicial Conference desempenha suas atividades principalmente através de numerosas comissões internas (em número aproximado de 25), as quais se reúnem assiduamente. Duas vezes ao ano são realizadas sessões plenárias.

${ }^{30}$ Compete a ela não somente providenciar no provimento e transferência dos servidores da justiça federal, como também resolver problemas administrativos da justiça federal, fazer recomendações ao Congresso relativamente à legislação de interesse do sistema judiciário federal, bem como preparar as regras processuais para a justiça federal. Desempenha ainda funções de orientação em matéria administrativa, relativamente aos órgãos judiciários de primeiro e segundo graus. Também é competente para aprovar o orçamento anual do sistema judiciário federal, com exceção do da Suprema Corte. Além disso, a Conference também tem competência disciplinar em relação aos juízes. Sobre tal órgão, consulte-se THE OXFORD COMPANION, 1992, p. 103 e BASSIOUNI, 1983, p. 442.

${ }^{31}$ Tradução livre: "Alguns diriam que os juízes são generalistas e apesar disso nós atribuímos ao judiciário estadual e federal [a decisão sobre] um amplo espectro de controvérsias. Esse argumento, porém, é falho, porque os juízes são especialistas em decidir problemas jurídicos. O judiciário busca resolver litígios com base em regras, ao passo que os mecanismos alternativos de resolução de controvérsias voltam-se a valores não jurídicos. Assim, se os litígios devem ser resolvidos com base em critérios legais, [então] os especialistas jurídicos indicados pelas nossas constituições estaduais e federal - isto é, os juízes - é que deverão decidi-los. Se, ao contrário, for conveniente que os litígios sejam resolvidos mediante aplicação de valores não jurídicos, então devemos reconhecer a necessidade de conhecimento específico sobre o tema."
} 
subsequente ao julgamento, não ainda necessariamente em fase de execução propriamente dita) (SILVESTRI, 1999, p. 328-329) $)^{32}$.

Não se pode, por isso, considerar os procedimentos alternativos de resolução de controvérsias (ADR) como se fossem uma panaceia. Ao contrário, os analistas têm chamado a atenção para os seguintes aspectos:

1. Do ponto de vista social e filosófico, justificou-se o surgimento das ADR a partir de uma dimensão quase que idílica e utópica de justiça, onde se realça o mecanismo da "conversação-negociação" entre os interessados, em busca da resolução consensual do conflito. Acontece, porém, que as ADR - tanto quanto a justiça ordinária - encontram-se a operar no âmago de uma realidade não simples nem harmônica, mas complexa e fortemente caracterizada pela explosão da litigiosidade, animosidade e desconfianças recíprocas;

2. Do ponto de vista de justiça social, algumas das suas técnicas podem contribuir para a manutenção das desigualdades socioeconômicas, quando envolvem partes econômica e socialmente desiguais ${ }^{33}$. Exemplo desta possibilidade nos é fornecido por M. H. Lazerson (1982, p. 119 et seq), no ensaio em que descreve o funcionamento da Housing Court de New York, instituída com o objetivo de resolver informalmente os conflitos entre inquilinos e locadores. Segundo este autor, o movimento dos inquilinos era fraco e desorganizado e por isto não conseguia obter melhorias substanciais de sua situação, via legislação. A composição informal dos conflitos individuais, por outro lado, não criava as condições necessárias para fazer avançar a situação global da categoria. Uma melhoria efetiva desta situação tornou-se possível somente quando a atuação mais crítica e politicamente orientada dos membros dos Legal Services (categoria que abrange, dentre outros, tanto os defensores públicos quanto os profissionais que se dedicam a uma advocacia pro bono) deslocou a arena de luta para a justiça ordinária, com todo o seu formalismo e garantismo processual. Só nessa sede o conflito social subjacente às controvérsias individuais pode eventualmente se revelar e ser levado em consideração. Em virtude da técnica do precedente, utilizada nos Estados Unidos, as decisões judiciais não só resolvem os conflitos individuais, mas também estabelecem parâmetros jurídicos a serem observados nas relações sociais futuras e indeterminadas, além de orientar mudanças na legislação.

3. Além disso, a "justiça particular" naturalmente acaba seguindo a lógica e as regras de mercado. A "justiça pública”, porém, tem força, condições e competência para fundamentar suas decisões em valores diversos, desempenhando uma função mais em conformidade com os princípios constitucionais e com as expectativas dos cidadãos (ALPA, 1986, p.623).

\footnotetext{
32 Sobre a questão, também SILVESTRI, 1999, p. 328-329.

33 Sobre os perigos de exploração da parte socialmente débil, v. as observações de M. Cappelletti (1993, p. 282-290) e de S. Chiarloni (1994, p. 419).
} 
Richard Abel (1982, p. 5 et seq), avaliando e referendando as conclusões de um seminário sobre sistemas informais de justiça, por ele organizado nos Estados Unidos, mostrou-se bastante cético em relação a tais sistemas. Ele tem dúvidas, por exemplo, se os sistemas informais de justiça podem efetivamente ajudar a desonerar o orçamento público. Segundo ele, esses sistemas complementam - e não substituem - os sistemas ordinários de justiça. Trata-se, portanto, de um gasto adicional e não de uma efetiva alternativa mais econômica. Além disso, como o custo operacional de uma unidade de justiça informal é menor (fundamentalmente porque o pessoal que ali atua tem uma qualificação profissional mais baixa e recebe, portanto, uma remuneração menor), fatalmente o sistema tenderá a multiplicar-se, anulando, assim, as economias obtidas.

Outro aspecto evidenciado por R. Abel consiste em que os sistemas informais de justiça, ao contrário do que se possa imaginar, não diminuem, mas sim aumentam, os controles estatais sobre a sociedade. Segundo ele, esses sistemas informais, por tenderem a estar disseminados por todas as camadas sociais, tendem a abranger conflitos que de outra forma jamais seriam submetidos a um aparato estatal formal (como a polícia e as cortes de justiça). Além disso, tais sistemas não estão sujeitos a muitos daqueles controles formais que ao longo do tempo surgiram, como decorrência do aumento das garantias dos direitos dos cidadãos frente ao aparato estatal.

Um dos principais motivos de preocupação consiste no fato de que os sistemas informais de justiça tendem a tornar triviais as queixas individuais, frustrando, assim, as respostas coletivas. A mensagem oculta desse sistema, sempre segundo R. Abel, consiste em convencer o cidadão comum de que pequenos problemas sociais podem ser resolvidos dentro do próprio sistema, sem que haja necessidade de colocar em discussão as estruturas sociais básicas. Em outras palavras, cada cidadão deve estar em condições de resolver sozinho (com a ajuda do sistema) o seu problema individual, não havendo necessidade de respostas globais. Assim, esses sistemas não percebem - ou fingem não perceber - que muitos litígios individuais, na verdade, nada mais são do que concretizações atomizadas de disfunções ínsitas a certas estruturas sociais.

Desta forma, tais disfunções existentes no campo macro, tendem a se manter e a se multiplicar no campo micro. Uma justiça que vise somente a compor amigavelmente os litígios individuais corre o risco de deixar intacta e incontroversa essas estruturas. Em certas hipóteses, é necessário o exercício da autoridade formal do juiz para evidenciar a existência de conflitos sociais latentes subjacentes ao litígio individual, trazê-los à tona, discuti-los e procurar remediá-lo à luz dos princípios e valores da justiça, individual e social.

Nesse sentido, citando Jean-Pierre Bonafé-Schimitt, Bolzan de Morais (1999, p. 109) refere que "a justiça deve prevalecer antes que a paz" e que "considerar a equivalência entre um acordo firmado e uma sentença proferida seria reduzir a função social da decisão jurisdicional a mera resolução de conflitos privados, o que privaria os tribunais de emitirem interpretações acerca de textos legais e a sociedade de ter a seu alcance autênticos critérios de justiça”. 
Atualmente, portanto, o debate doutrinário sobre as alternativas ao processo judicial concentra-se sobre o problema de como conciliar a busca de formas procedimentais que assegurem uma justiça mais rápida e mais acessível que a ordinária, com a exigência de salvaguardar as garantias da defesa.

\section{FORMAS ALTERNATIVAS DE COMPOSIÇÃO DE CONFLITOS NO DIREITO BRASILEIRO: FRAGILIDADES E CONQUISTAS}

O Direito é um produto da cultura de um povo, não podendo ficar imune a experiências estrangeiras, especialmente em um mundo globalizado como o de hoje, mas também qualquer assimilação deve ser compreendida, pena de produzir resultado contrário ao pretendido, no âmbito da tradição responsável pelo paradigma praticado e cuja revitalização se objetiva.

Nesse sentido, é preciso firmar que em sede de jurisdição e processo civil, o direito brasileiro está ideologicamente comprometido com o modelo da jurisdição romano-canônica (SILVA, 1997), de cujas amarras inúmeras tentativas foram e estão sendo levadas a efeito, mas que ainda encontram resistências na comunidade jurídica $^{34}$, e, por vezes, enfrentam algum retrocesso.

Um dos legados da modernidade foi o individualismo, concentrando-se o mundo - e o conhecimento no sujeito, como se fosse uma nova concepção do universo - por primeiro, a terra como centro do universo, seguindo-se o sol, e agora o indivíduo -, lembrando-se, aqui, a famosa frase de Descarte: penso, logo existo! O Direito como um todo, e o que importa mais de perto, o Direito Processual Civil, não ficaram imunes a essa vertente. A partir da estruturação teórica do iluminismo e do racionalismo, por mais de duzentos anos elegeu-se um paradigma de processo e jurisdição marcados, respectivamente, pela ordinariedade e pela declaração da vontade da lei, num verdadeiro movimento de desconstrução da jurisdição enquanto emanação do direito material, do juízo de valor e de verossimilhança. Essa é a constatação de Ovídio Baptista ao demonstrar a mutilação que esse processo histórico provocou, transformando a jurisdição em mera declaração, tudo em homenagem à segurança jurídica (SILVA, 2009, p. 109-110).

E o Brasil, seja por sua origem colonial, incorporando a tradição lusitana, seja porque o paradigma continental europeu bem se amoldou a um país que durante o último século da colonização portuguesa e os primórdios do século XX assentou-se como uma nação territorialmente gigantesca, mas de produção substancialmente agrícola, onde importante para a classe produtiva e governante era exatamente a manutenção do statu quo (valor alcançado pela lei), culminou por recepcionar à extravagância, em especial pelo Código de Processo Civil de 1973, o paradigma da racionalidade. Isso levou ao absoluto divórcio entre a função intrínseca da

\footnotetext{
${ }^{34}$ Exemplo maior, o instituto da antecipação de tutela, introduzido no processo de conhecimento pelas reformas de 1994 e até então avesso a qualquer comando executivo, cuja desconfiança vem expressa no próprio texto legislativo que limita sua incidência às hipóteses de "inequívoca verossimilhança”, acusando uma contradição interna na regulamentação do instituto.
} vol.09, nº. 01, Rio de Janeiro, 2016.pp. 510-544 
jurisdição e a jurisdição prestada pelos juízes e tribunais pátrios, estabelecendo-se o que se passou a conhecer como "crise do Poder Judiciário" ou "crise da jurisdição" ou ainda "crise do procedimento ordinário".

As primeiras reações remontam aos anos oitenta (século XX) e são de duas classes: a formação de uma justiça paralela, mas vinculada ao aparato da justiça do Estado e a introdução de técnicas de sumarização da própria jurisdição, adequando-se o processo às necessidades do direito material e da vida cotidiana. Nenhuma dessas soluções representa uma fuga da jurisdição, mas sim sua revitalização e que por isso mesmo continuaram sendo objeto de aperfeiçoamento legislativo, em reformas legislativas posteriores. Posteriormente, já nos anos noventa, agora abstraindo-se do Judiciário, valorizou-se o reconhecimento da jurisdição privada, normatizando-se através de lei o instituto da arbitragem. Paralelamente, foi objeto de discussão por longos anos, só recentemente sobrevindo sua positivação (BRASIL, 2015), o instituto da mediação, que nesse interim passou a ser adotado mais por iniciativa de certos grupos independentes ou como ativismo judicial, protagonizado inclusive pelo próprio CNJ - Conselho Nacional da Justiça. Como novidade, o novo CPC, Lei n. 13.105, de 16.03.15, que institui o processo consensual, prevendo mecanismos institucionais e processuais para sua adoção. Em apertada síntese, esses os movimentos que o Brasil nos últimos trinta anos enfrentou e vem enfrentando para recompor ou superar o desgaste que a jurisdição e o processo tradicional sofreram, a seguir objeto de desdobramento.

\section{Juizados de Pequenas Causas versus Juizados Especiais Cíveis}

Em 1984, pela Lei 7.244, introduziram-se no direito pátrio os Juizados de Pequenas Causas, como reação à morosidade, complexidade, custo econômico do processo tradicional, já à vista sua inaptidão para cumprir sua função social de pacificação e de distribuição dos bens juridicamente tutelados. Exigia-se um novo modelo, ainda que concentrado no seu aspecto formal, que pudesse, de forma econômica, simples, célere, com predomínio da oralidade, resolver conflitos cuja complexidade fática ou jurídica dispensassem os excessos de formalismo que o processo tradicional tende a contemplar, autêntica herança do racionalismo e seu produto direto, o positivismo jurídico, como acusa Dallari (1996, p. 80-81).

Nesta primeira versão, a lei contemplava junto à Justiça Estadual a criação de juizados, inicialmente como juizados adjuntos às unidades judiciárias da justiça comum, com o fito de processar e julgar determinadas demandas especificadas ou pela matéria ou pelo (pequeno) valor da causa, que admitissem solução por um rito sumaríssimo, em que se priorizava a conciliação, a concentração de atos, prazos mais curtos, simplicidade procedimental e oralidade, ficando a presença de advogado a critério da própria parte.

O sistema atribuía a um juiz togado a condução dos Juizados, o processamento dos feitos e a decisão da causa. Nessa função, podia ele ser auxiliado por conciliadores que, em fase anterior à contestação e à produção da prova, em audiência própria, buscavam a conciliação. Caso obtida esta, submetia-se-a ao juiz de direito (apenas a 
Justiça estadual estava autorizada a implementar os Juizados de Pequenas Causas) para fins de homologação. Buscava-se alcançar uma sentença que se qualificava como título executivo judicial, ponto crítico no procedimento regulado pela Lei n. 7.244/84, já que não se previa eventual execução caso não houvesse o cumprimento espontâneo da decisão judicial.

Embora a figura do juízo arbitral fosse contemplada no respectivo estatuto, sua aplicação prática foi quase inexistente.

O sistema dos Juizados de Pequenas Causas foi de certo modo bem recebido no meio jurídico e por seus usuários, mas longe estava de ser uma unanimidade, sendo a principal resistência ofertada pelos advogados, na medida em que o texto legal permitia o comparecimento das partes desprovidas de capacidade postulatória, o que até então era inusitado em termos processuais. Por outro lado, o novo instrumento de composição de conflitos garantiu o mais amplo acesso à justiça por aqueles que se viam despojados desta garantia pelas dificuldades que o processo tradicional representava, além de obterem resultados práticos, com composição e/ou decisões ocorrentes em curto espaço de tempo.

Com o advento da Constituição de 1988, restou estabelecido o dever de criação, pela União, Distrito Federal e Territórios e pelos Estados, de juizados especiais, providos por juízes togados ou togados e leigos, com o fito de conciliar, processar, julgar e executar causas cíveis de menor complexidade e infrações penais de menor potencial ofensivo (art. 98, inciso I, CF). Foram priorizados os procedimentos oral e sumaríssimo, o que veio consagrar a experiência pretérita com uma maior amplitude, estendendo-se sua atuação também para as demandas criminais e aquelas de competência da Justiça Federal ${ }^{35}$. Para regulamentar os Juizados Especiais, foi editada a Lei n. 9.099/95, abrangendo tanto o procedimento cível como o criminal, seguida da Lei n. 10.259/01, que regulamenta os Juizados Especiais Federais. A jurisdição prestada no âmbito dos Juizados Especiais se modula pelos critérios da oralidade, simplicidade, informalidade, economia processual e celeridade do processo, buscando, sempre que possível, a conciliação ou a transação, cuja atuação fica a cargo de juízes togados e juízes leigos, com o auxílio de conciliadores.

Os dados publicados pelo Conselho Nacional da Justiça, em 2014, exclusivamente em relação à Justiça Estadual, para todo o território nacional, em ambos os graus de jurisdição, acusavam um estoque de processos de 53.952.374, dos quais 5.152.990 representavam o estoque dos processos junto aos JEC, ou seja, cerca de $10 \%$ do total apurado. No mesmo período, foi constatado que adentraram no primeiro grau da justiça comum um total de 14.965.077 feitos novos, enquanto que para os JEC o ingresso de novos feitos ficou em 5.317.104, também em ambos os graus de conhecimento. Considerando o número de julgamentos realizados por ambos os segmentos, a

\footnotetext{
35 A Justiça do Trabalho, através da Lei no 9.957, de 12 de janeiro de 2000, estabeleceu um procedimento sumaríssimo, relativamente aos dissídios individuais trabalhistas cujo valor não exceda a 40 vezes o salário mínimo, na data do ajuiza mento da reclamação, seguindo a orientação implementada pela Justiça Comum Cível.
} 
justiça ordinária alcançou os percentuais de 101,1\% nos tribunais e 91,5\% no primeiro grau, enquanto que nas turmas recursais o percentual de processos baixados ficou em 83,7\% (abaixo dos tribunais) e junto aos juizados o percentual alcançou 95,8\% (acima do primeiro grau da justiça comum). Percebe-se que independentemente de uma diferença significativa entre os índices de um ou de outro segmento, ainda se tem um alto grau de produtividade que se mostra alvissareiro em relação ao microssistema dos juizados especiais, merecendo sua manutenção e aperfeiçoamento no ordenamento jurídico pátrio (CONSELHO NACIONAL DE JUSTIÇA, 2014).

De qualquer sorte, a opção dos Juizados Especiais representa uma fuga da jurisdição ordinária, comum e tradicional, mas permanece sendo de foro público, cuja organização e atuação é de atribuição do Poder Judiciário.

\section{$\underline{\text { Arbitragem }}$}

O Código de 1973 previa o juízo arbitral como um procedimento especial, em que as partes escolhiam um árbitro para compor o conflito, mas cuja resolução teria que ser submetida à homologação judicial para poder produzir efeitos. A previsão, à evidência, tornou-se absolutamente inútil, não se tendo conhecimento de sua utilização ou reduzindo-se a mesma a casos insignificantes. Nitidamente um instrumento em desuso.

Com os novos ares promovidos pela Constituição de 1988, foi editada a Lei n. 9.307/96, que instituiu a arbitragem, estabelecendo o seu art. 10: "as pessoas capazes de contratar poderão valer-se da arbitragem para dirimir litígios relativos a direitos patrimoniais disponíveis", revogando as disposições constantes do CPC sobre o juízo arbitral e autorizando soluções com base no direito e na equidade. Isso representou a construção de um novo paradigma para a realidade brasileira, com o reconhecimento de uma jurisdição privada, rompendo com o dogma de que toda jurisdição necessita ser pública. Mais recentemente, pela Lei n. 13.129/15, a arbitragem foi reformulada, modernizando o instituto, inclusive permitindo sua utilização pela administração pública direta e indireta.

Duas são as formas previstas para a instauração da convenção da arbitragem: a cláusula compromissória, estabelecida em contrato, que antecede o conflito, vinculando às partes ao que foi avençado e afastando, no caso, a intervenção do poder público; e o compromisso arbitral, que consiste numa convenção entre as partes já em litígio, mas que optam por depositar a solução nas mãos de um árbitro. A opção pode ser celebrada no curso de um processo judicial, que restará destarte prejudicado, ou, ainda, através de escrito particular firmado pelos contratantes e duas testemunhas ou por instrumento público, evitando-se, desta sorte, a propositura da demanda judicial.

A figura do árbitro é regulada pela Lei da Arbitragem, podendo ser qualquer pessoa da confiança das partes, mas ao qual se aplicam inúmeras regras que regem a atuação do juiz público, como as causas de 
impedimento e suspeição, e a sentença arbitral tem força de título executivo judicial, na medida em que a arbitragem não detém o império da execução.

O novo Código de Processo Civil, ao tratar do tema no capítulo das normas fundamentais do processo, confirma o instituto da arbitragem ${ }^{36}$, limitando-se a regular eventual diálogo entre as duas jurisdições - a pública e a privada - seja na manutenção da sentença arbitral como título executivo judicial ${ }^{37}$, seja na previsão da cooperação entre o juízo arbitral e o juiz togado ${ }^{38}$. No capítulo que regula a alegação de convenção de arbitragem, em eventual fuga da jurisdição privada para a jurisdição pública, estabelece a hipótese de extinção do processo sem resolução de mérito, quando reconhecida a convenção de arbitragem ${ }^{39}$.

O instituto da arbitragem já alcançou uma certa maturidade nesses quase vinte anos de sua previsão legislativa, havendo inúmeras iniciativas no sentido de sua concretização ${ }^{40}$, mas ainda se ressente de uma carência de coleta de dados concretos, públicos e oficiais, sobre a atuação dos órgãos arbitrais, a natureza das causas enfrentadas, o tempo de duração, o custo e êxito de soluções. Apesar disso, já se pode ter por consistente a literatura sobre a temática.

\section{$\underline{\text { Mediação }}$}

A Mediação, no Brasil, foi recepcionada pelo direito positivo através da recente Lei n. 13.140, de 26 de junho de 2015, embora, como já afirmado anteriormente, iniciativas no âmbito do Poder Judiciário foram levadas a efeito com o fito de estimular a mediação e evitar a resolução do conflito através da tradicional intervenção da jurisdição pública, via processo comum. Inspiraram-se as práticas locais em doutrina alienígena e em doutrinadores nacionais que recepcionam o instituto, apontando-o como uma solução eficiente para a alternativa da crise do Judiciário. Apostando nesta saída, o Conselho Nacional da Justiça, pela Resolução n. 125/2010, atualizada em 2013, instituiu a Política Judiciária Nacional de tratamento dos conflitos de interesses, tendente a assegurar a todos o direito à solução dos conflitos por meios adequados à sua natureza e peculiaridade. Para tanto, determinou-se aos tribunais criar Núcleos Permanentes de Métodos Consensuais de Solução de Conflitos, compostos por magistrados da ativa ou aposentados e servidores, preferencialmente atuantes nas áreas afins, reconhecendo para tais membros ou integrantes, entre outras, a atividade de mediação.

De outro lado, no âmbito das relações trabalhistas, o Decreto 1.572 de 28 de julho de 1995 regulamenta a mediação na negociação coletiva de natureza trabalhista e, em seu artigo $4^{\circ}$, traz a previsão de o Ministério do Trabalho e Emprego constituir um cadastro de mediadores aptos para subsidiar a escolha pelas partes

\footnotetext{
${ }^{36}$ Lei n. $13.105 / 2015$, art. $3^{\circ}, \$ 1^{\circ}$ : é permitida a arbitragem, na forma da lei.

${ }^{37}$ Idem, arts. 515, inciso VII, e 516, inciso III.

${ }^{38}$ Idem, art. 69, $\$ 11^{\circ}$.

${ }^{39}$ Idem, arts. 337, inciso X, e 485, inciso VII. 345 a 350.
}

${ }^{40}$ Remete-se o leitor para o site do http: //cbar.org.br/site/: Comitê Brasileiro de Arbitragem. vol.09, n. 01, Rio de Janeiro, 2016.pp. 510-544 
(TAVARES et al, 2013), representando um avanço em relação à área cível, ainda que o texto se limite às negociações coletivas e não às individuais.

No Estado do Rio Grande do Sul, o Tribunal de Justiça, seguindo orientação do CNJ, investiu nesta proposta, instituindo o Núcleo Permanente de Métodos Consensuais de Solução de Conflitos. Dentre outras atividades, esse Núcleo Permanente tem promovido, a exemplo da III Jornada de Mediação, espaço de discussão objetivando reunir estudantes, mediadores, magistrados e o público em geral para debater o tema, apostando na mediação como marco transformador do Judiciário e abrindo novas formas de acesso à justiça (ALBERTON, 2014, p.3).

A iniciativa, antecedendo à atuação do Legislativo, certamente meritória, vem ao encontro de um repensar dos meios tradicionais de superação de conflitos, mas peca por abarcar a sua institucionalização e aplicação na organização e intervenção do Poder Judiciário, cuja atividade de império (força vinculante da decisão) é intrinsicamente incompatível com a atividade de mediação, que atua sob outros princípios e práticas. Necessário, pois, mesmo sob os auspícios do Poder Judiciário, criar espaços e ambientes independentes, tanto quanto possível afastados do meio judiciário, pena de prejudicar o encontro e o diálogo que as partes em mediação carecem para exercerem suas escolhas. A nova lei permite que esse caminho seja adotado, mas ainda há um forte vínculo com o Poder Judiciário, especialmente no que diz com a composição do conflito, que guardará força de título executivo judicial, se homologado judicialmente, o que abre uma porta para a judicialização da mediação. Execução, cediço, gera controvérsias que podem ser levantadas ou através de embargos ou de impugnação ao cumprimento da sentença.

De qualquer sorte, tais experiências pretéritas, por óbvio, deverão ser consideradas e adaptadas às exigências, agora, da lei de regência, uma nova etapa da mediação no Brasil.

O novel estatuto contempla a previsão de mediação como meio de solução de controvérsias entre particulares e como autocomposição em conflitos no âmbito da administração pública, adotando, expressamente, a mediação judicial e a extrajudicial, podendo versar sobre todo o conflito ou parte dele. Esta nova fase da mediação, face à Lei n. 13.140/15, vem em bom momento, na medida em que se edita um novo Código de Processo Civil, que estimula a resolução dos conflitos pelas formas de autocomposição e contribui com regras específicas voltadas à mediação judicial.

\section{Técnicas de sumarização da jurisdição e os provimentos provisórios}

Como já referido alhures, após os primeiros vinte anos do Código de 1973, a constitucionalização do processo e a garantia de uma justiça acessível, tempestiva e efetiva, o surgimento de novos direitos cuja satisfação pela via do processo tradicional vinha se mostrando inviável, a era do "tempo real" para as mais comezinhas 
necessidades, entre outros fatores, provocaram uma reação no processo civil. Revitalizaram-se técnicas processuais ao efeito de uma prestação jurisdicional substancializada, gerando alterações legislativas que viabilizassem esse novo paradigma. Enumerar tais modificações exigiria espaço próprio de pesquisa, razão pela qual aqui apenas serão apontados o novo CPC e o instituto da tutela provisória.

Impactante, no presente, a edição do novo Código de Processo Civil, Lei n. 13.105, de 16/03/2015, com vacatio legis de um ano. No mesmo fio das reformas antecedentes, o novo estatuto revoluciona a matéria, tratando da tutela provisória, mediante provimentos antecipatórios satisfativos, cautelares e de tutelas de evidência, em livro próprio (da tutela provisória) ${ }^{41}$, no âmbito da Parte Geral, revogando o Processo Cautelar, tão festejado no Código de 1973. A inserção da tutela provisória na Parte Geral do código autoriza concluir que tais provimentos se estendem ao processo de conhecimento e ao processo de execução, que passam a ser tratados na parte especial, e, também aos feitos de competência dos tribunais, sejam em sede de jurisdição recursal ou originária.

Trata-se, em apertada síntese, de providências que buscam atribuir ao processo tradicional novos mecanismos de efetividade, tempestividade e de maior aderência ao direito material, oxigenando-o e alimentandoo com medidas de natureza executiva e/ou mandamental, onde o poder de decidir ganha mais espaço (materialização do processo), em detrimento do ato de julgar (sumarização da jurisdição).

A nova proposta legislativa, ainda que se sirva da experiência pretérita, objetiva uma simplificação das espécies de medidas satisfativas e cautelares, evitando a velha doutrina que se aperfeiçoou em distingui-las, ao efeito de aproximá-las e, até, permitindo uma maior fungibilidade no seu trato. Agrega, ainda, o novo texto, com regras próprias, a tutela de evidência, dando-lhe corpo e identidade, o que não chega a ser uma novidade, pois já vinha ela anunciada no Código de 1973, ainda que timidamente, com a reforma de 2002, quando incluído no art. 273 o $\$ 6^{\circ}$, autorizando que o juiz antecipasse os efeitos de um ou mais dos pedidos cumulados, ou parcela deles, se incontroversos. Introduziu, também, aí sim como novidade, a estabilidade da tutela antecipada requerida em caráter antecedente, prevista para a hipótese em que o autor postule tutela antecipada, quando a urgência for contemporânea à propositura da ação, e, uma vez concedida, o réu não se opõe ao comando interdital deixando de recorrer da decisão, o que levará à extinção do processo. O instituto guarda aproximação ao réferé do direito francês (SALDANHA, 2011, p. 376-377) e à técnica de monitorização do processo, tão bem desenvolvida pelos italianos, mas, ao mesmo tempo, dessas inspirações se afasta. No primeiro caso, porque não há jurisdições distintas entre o juiz que concede a antecipação de tutela em caráter antecedente e o que julgará, se for o caso, em caráter definitivo o conflito, confundindo-se ambas as decisões perante o mesmo juízo; e, no segundo caso, porque a via processual que a lei oferta ao demandado (interposição de recurso) não é propriamente a de inversão do

\footnotetext{
${ }^{41}$ Lei n. 13.105/2015, arts. 294 a 311.
} 
contraditório, na medida em que não estabilizada a decisão de urgência o processo se ordinariza e o réu se valerá do contraditório pleno, opondo-se ao pleito do autor através de contestação.

De qualquer sorte, a preocupação do legislador processual vem ao encontro do reconhecimento que o processo tradicional, ordinário e declarativo, mostra-se obsoleto como única via para a resolução dos conflitos. $\mathrm{O}$ aparato judiciário, pena de tornar-se fragilizado e passível de substituição, carece reinventar-se, ou, ainda, conviver com formas alternativas na função maior da pacificação social e distribuição dos bens da vida, que certamente não se esgotam no espaço público, sendo um comprometimento da sociedade como um todo.

\section{CONSIDERAÇÕES FINAIS}

Como se viu do presente ensaio, o movimento das Alternative Dispute Resolution ainda não está completamente sedimentado. As avaliações que se fazem quanto à sua operacionalidade e aos resultados obtidos não são unânimes. Ao lado dos seus defensores encontram-se muitos críticos e, ao fim e ao cabo, o problema, quiçá, deva ser encarado de forma maniqueísta. A questão é complexa e não exige soluções extremadas de adesão integral ou de franca repulsa. Quem sabe o mais conveniente seja identificar os setores nos quais é indispensável a intervenção de uma magistratura profissional, pública, organizada de forma independente, que opere mediante procedimentos formalizados. Esta forma de exercício de jurisdição, que necessariamente tem um custo orçamentário mais imponente, deveria ser encarregada de resolver somente os conflitos que não podem ou não devem ser solucionados mediante controles administrativos prévios (com atuação de agências regulatórias autônomas e que efetivamente se comportem como agentes da sociedade, e não como defensoras de grupos de interesses), ou mediante procedimentos de mediação ${ }^{42}$ e de resolução alternativa de conflitos, por árbitros/mediadores não estatais. Esses outros agiriam como uma espécie de justiça complementar, alternativa, talvez "menor", mas não necessariamente contraposta à justiça togada.

Afinal, um dos motivos principais que pode levar um potencial usuário do sistema de justiça a procurar sistemas mais informais reside na preferência por uma justiça mais econômica e célere. Todavia, também é verdade que, muitas vezes, o fator "justiça" é mais importante do que o fator "celeridade" - e o cidadão, muitas vezes, está disposto a pagar o preço, sentindo-se mais albergado pela justiça pública e pelo poder de império ínsito a tais atividades.

\footnotetext{
${ }^{42} \mathrm{O}$ resultado das pesquisas levadas a efeito nos Estados Unidos demonstra que a mediação tem uma maior efetividade quando ambas as partes admitem uma parcial responsabilidade pelo conflito. Em circunstâncias em que há uma clara resposta do sistema para uma determinada controvérsia, onde uma parte possui nítido direito a algo, uma regular decisão judicial pode ser mais efetiva, uma vez que, nessas hipóteses, será mais difícil obter um acordo. A mediação, assim, pode ser mais apropriada naquelas situações em que as partes encontram-se no centro, estando cada uma delas disposta a fazer recíprocas concessões, diante do resultado incerto da solução jurídica da controvérsia.
} 
O fato é que a $\mathrm{ADR}$ não veio para substituir o processo judicial tradicional, mas sim para colocar-se como opção ao seu lado. Pode também haver uma interação, no sentido que o deslocamento momentâneo de certas causas para as técnicas de ADR acabará por diminuir o fluxo das demandas judiciárias. Com uma menor carga de trabalho, os juízes tenderão a resolver mais rapidamente os processos ao seu encargo. E uma maior celeridade da justiça comum tornará novamente atraente a via judicial, chegando-se, destarte, a um novo ponto de equilíbrio

No direito pátrio, à maneira brasileira, também se trabalha para encontrar formas alternativas à jurisdição tradicional na realização e concretização dos direitos dos homens. Não há resposta fácil, nem caminho que dispense construção. Por vezes, reforçar o público e modernizá-lo com técnicas mais aderentes ao direito material, em outras, abrir novos espaços, novas frentes, novas técnicas ou ainda estimular o privado em prol das autocomposições.

Não há magia ou milagres, nem soluções perfeitas, mas um constante reconstruir-se, reinventar-se, refazer-se, podendo até afirmar-se que a fuga à jurisdição, mais que fuga é, sim, um reencontrar-se.

\title{
ESCAPING JURISDICTION? REFLECTIONS ON THE SEARCH FOR ALTERNATIVES TO JURISDICTION
}

\begin{abstract}
The present essay analyses the so-called ADR movement (Alternative Dispute Resolution), its origin, development and ideology, specially in the United States. References are made to the different ADR techniques that are used, and the arguments that commonly are invoked to sustain or to criticize it. It also focus on Brazilian experiences either on summarization of jurisdiction techniques or the construction of public or private spaces for alternative dispute resolution and the contribution of de new CPC.
\end{abstract}

Keywords: ADR. Alternative Dispute Resolution. American Justice. Comparative Law. Brazilian experiences.

\section{REFERENCIAS BIBLIOGRÁFICAS}

ABEL, Richard L. (ed.). The Politics of Informal Justice. V. 1 - The American Experience. New York: Academic Press, 1982.

ABRAHAM, Henry J. The Judicial Process - An Introductory Analysis of the Courts of the United States, England, and France. 7.ed. New York: Oxford University Press, 1998.

ALBERTON, Genacéia da Silva. III Jornada de Mediação e o marco de transformação do Judiciário. Jornal O Sul, Caderno Colunistas, 17.08.14. 
ALPA, Guido. Riti alternativi e tecniche di risoluzione stragiudiziale delle controversie di diritto civile. In: BESSONE, Mario (org.) L'attività del giudice. Mediazione degli interessi e controllo delle attivitá. Torino: Giappichelli, 1997.

ALPA, Guido. Il disordine legislativo, la creatività della giurisprudenza e il caso della giustizia civile. Politica del diritto. Ano XVII, n. 4, 1986.

ANDREWS, Neil. O moderno processo civil - formas judiciais e alternativas de resolução de conflitos na Inglaterra. 2.ed. São Paulo: Revista dos Tribunais, 2012.

BASSIOUNI, M. Cherif. The Judicial System of the United States, An Overview. In: PICCARDI, Nicola e GIULIANI, Alessandro (org.). L'ordinamento giudiziario, v. II - Documentazione comparativa. Rimini: Maggioli Ed., 1983.

BRASIL. Código de Processo Civil. Lei federal no 13.105. São Paulo: Revista dos Tribunais, 2015.

BENDER, R. "The Stuttgart Model”. In: CAPPELLETTI, Mauro (org.) Access to Justice. V. II, book 2. Milano: Giuffrè, 1979.

BIERBRAUER, G., FALKE, J. e KOCH, K.-F. Conflict and its Settlement: An Interdisciplinary Study Concerning the Legal Basis, Function and Performance of the Institution of the Schiedsmann. In: CAPPELLETTI, Mauro (org.), Access to Justice, v. II, book 1 (Promising Institutions). Milano: Giuffrè, 1978.

CADIET, Loïc. I modi alternativi di regolamento dei conflitti in Francia, fra tradizione e modernità. In: VARANO, Vincenzo. L’Altra Giustizia. Milano: Giuffrè, 2007.

CAPPELLETTI, Mauro. Alternative Dispute Resolution Processes within the Framework of the World-Wide Access-to-Justice Movement. Modern Law Review, v. 56, 1993.

CHASE, Oscar. Il problema della durata del processo civile in Italia e negli Stati Uniti. Rivista Trimestrale di Diritto e Procedura Civile, 1988.

CHIARLONI, Sergio. Nuovi modelli processuali. In: VISINTINI, Giovanna (org.). Il diritto dei nuovi mondi. Padova: Cedam, 1994.

CHIARLONI, Sergio. Avvocature e ordinamento giudiziario. Rassegna Forense, 1995, n. 1-2.

CHIARLONI, Sergio. La conciliazione stragiudiziale come mezzo alternativo di risoluzione delle dispute. Rivista di Diritto processuale, 1996, v. II.

CONSELHO NACIONAL DE JUSTIÇA. Justiça em números. Disponível em: <ftp://ftp.cnj.jus.br/Justica_em_Numeros/relatorio_jn2014.pdf>. Acesso em: 08 out. 2015.

CORNU, Gérard \& FOYER, Jean. Procédure civile. 3.ed. Paris: P.U.F., 1996.

DALLARI, Dalmo de Abreu. O poder dos juízes. São Paulo: Saraiva, 1996.

DAYTON, K. The Myth of Alternative Dispute Resolution in the Federal Courts. Iowa Law Review, v. 76, 1991. 
DENTI, Vittorio. I procedimenti non giudiziali di conciliazione come istituzioni alternative. Rivista di Diritto Processuale, 1980.

DE PALO, Giuseppe; GUIDI, Guido. Risoluzione alternativa delle controversie (ADR) nelle corti federali degli Stati Uniti. Milano: Giuffrè, 1999.

DINAMARCO, Cândido R. A Instrumentalidade do Processo. São Paulo: Ed. Rev. dos Tribunais, 1987.

EDWARDS, H. T. Alternative Dispute Resolution: Panacea or Anathema?. Harvard Law Review, v. 99, 1986.

FISS, Owen. Um novo processo civil. Estudos norte-americanos sobre jurisdição, constituição e sociedade (org. por Carlos Alberto de Salles). São Paulo: Ed. Revista dos Tribunais, 2004.

GARNER, Bryan A. Dictionary of Modern Legal Usage. Oxford: Oxford University Press, 1995.

GARNER, Bryan A. (Editor in Chief). Black's Law Dictionary. 8.ed. Saint Paul: Thompson/West, 2004.

GOTTWALD, P. Civil Procedure Reform in Germany. American Journal of Comparative Law, v. 45, 1997.

GUIDE DO JUDICIAL MANAGEMENT OF CASES IN ADR. Washington: Federal Judicial Center, 2001.

GUILL, Terenia U. A Framework for Understanding and Using ADR. Tulane Law Review, v. 71, 1997.

HAZARD, Geoffrey C.; JAMES, Fleming \& LEUBSDORF, John. Civil Procedure. 4.ed. Boston: Little, Brown and Company, 1992.

LAZERSON, Mark H. In the Halls of Justice, the Only Justice Is in the Halls. In: ABEL, Richard L. (ed.). The Politics of Informal Justice, v. 1 - The American Experience. New York: Academic Press, 1982.

LIMA FILHO, Francisco das Chagas. Acesso à justiça e os mecanismos extrajudiciais de solução de conflitos. Porto Alegre: Sergio A. Fabris Ed., 2003, p. 246.

McGOVERN, F. E. Rethinking Cooperation Among Judges in Mass Tort Litigation. UCLA Law Review, vol. 44 (1977).

MENKEL-MEADOW, C. When Dispute Resolution Begets Disputes of Its Own: Conflicts Among Dispute Professionals. UCLALaw Review, v. 44, 1997.

MOORE, Christopher W. O Processo de Mediação - Estratégias Práticas para a Resolução de Conflitos. 2.ed. Porto Alegre: Artmed, 1998.

MORAIS, José Luis Bolzan de. Mediação e Arbitragem - Alternativas à Jurisdição!. Porto Alegre, Livraria do Advogado, 1999.

OXFORD COMPANION to the Supreme Court of the United States. New York: Oxford University Press, 1992. 
POSNER, Richard A. The Federal Courts - Challenge and Reform. 2.ed. Cambridge, Massachusetts: Harvard University Press, 1996.

RE, Edward D. Sovraccarico, lentezza, e costi del processo in U.S.A. Rivista di Diritto Civile, vol. XXXII, t. I, 1986.

REHNQUIST, William H.. Seen in a Glass Darkly: The Future of the Federal Courts Wisconsin Law Review, 1993.

RESNIK, J. Managerial Judges. Harvard Law Review, v. 96, 1982.

RESNIK, J. Risoluzione alternativa delle controversie e processo: uno sguardo alla situazione nordamericana. Rivista Trimestralle di Diritto e Procedura Civile, v. 51, 1997.

SCHLOSSER, Peter. Alternative Dispute Resolution (uno stimolo alla riforma per l'Europa?). Rivista di Diritto Processuale, 1989.

SILVA, Ovídio A Baptista da. Jurisdição e execução na tradição romano-canônica, São Paulo: Revista dos Tribunais, 1997.

Epistemologia das ciências culturais, Porto Alegre: Verbo Jurídico, 2009.

SILVESTRI, Elisabetta. La 'court-annexed arbitration': un nuovo rimedio per un vecchio problema. In: BESSONE, Mario (org.). L'attività del giudice. Mediazione degli interessi e controllo delle attività. Torino: Giappichelli, 1997.

SILVESTRI, Elisabetta. Osservazioni in tema di strumenti alternativi per la risoluzione delle controversie. Rivista Trimestralle di Diritto e Procedura Civile, 1999.

VARANO, Vincenzo (org.). L’Altra Giustizia. Milano: Giuffrè, 2007.

Trabalho enviado em 13 de dezembro de 2015.

Aceito em 14 de janeiro de 2016. 